\title{
Variations in time and space of trace metal aerosol concentrations in urban areas and their surroundings
}

\author{
T. Moreno ${ }^{1}$, X. Querol ${ }^{1}$, A. Alastuey ${ }^{1}$, C. Reche ${ }^{1}$, M. Cusack ${ }^{1}$, F. Amato ${ }^{1}$, M. Pandolfi ${ }^{1}$, J. Pey ${ }^{1}$, A. Richard ${ }^{2}$, \\ A. S. H. Prévôt ${ }^{2}$, M. Furger ${ }^{2}$, and W. Gibbons ${ }^{3}$ \\ ${ }^{1}$ Institute of Environmental Assessment and Water Research, Spanish Research Council (IDÆA-CSIC), C/Jordi Girona \\ 18-26, 08034 Barcelona, Spain \\ ${ }^{2}$ Laboratory of Atmospheric Chemistry, Paul Scherrer Institut, 5232 Villigen, Switzerland \\ ${ }^{3}$ AP 23075, Barcelona 08080, Spain
}

Received: 11 March 2011 - Published in Atmos. Chem. Phys. Discuss.: 13 May 2011

Revised: 20 July 2011 - Accepted: 4 September 2011 - Published: 12 September 2011

\begin{abstract}
Using an unprecedentedly large geochemical database, we compare temporal and spatial variations in inhalable trace metal background concentrations in a major city (Barcelona, Spain) and at a nearby mountainous site (Montseny) affected by the urban plume. Both sites are contaminated by technogenic metals, with $\mathrm{V}, \mathrm{Pb}, \mathrm{Cu}, \mathrm{Zn}$, $\mathrm{Mn}, \mathrm{Sn}, \mathrm{Bi}, \mathrm{Sb}$ and $\mathrm{Cd}$ all showing upper continental crust (UCC) normalised values $>1$ in broadly increasing order. The highest metal concentrations usually occur during winter at Barcelona and summer in Montseny. This seasonal difference was especially marked at the remote mountain site in several elements such as Ti and Rare Earth Elements, which recorded campaign maxima, exceeding $\mathrm{PM}_{10}$ concentrations seen in Barcelona. The most common metals were $\mathrm{Zn}$, Ti, $\mathrm{Cu}, \mathrm{Mn}, \mathrm{Pb}$ and $\mathrm{V}$. Both $\mathrm{V}$ and $\mathrm{Ni}$ show highest concentrations in summer, and preferentially fractionate into the finest $\mathrm{PM}$ sizes $\left(\mathrm{PM}_{1} / \mathrm{PM}_{10}>0.5\right)$ especially in Barcelona, this being attributed to regionally dispersed contamination from fuel oil combustion point sources. Within the city, hourly metal concentrations are controlled either by traffic (rush hour double peak for $\mathrm{Cu}, \mathrm{Sb}, \mathrm{Sn}, \mathrm{Ba}$ ) or industrial plumes (morning peak of $\mathrm{Ni}, \mathrm{Mn}, \mathrm{Cr}$ generated outside the city overnight), whereas at Montseny metal concentrations rise during the morning to a single, prolonged afternoon peak as contaminated air transported by the sea breeze moves into the mountains. Our exceptional database, which includes hourly measurements of chemical concentrations, demonstrates in more detail than previous studies the spatial and temporal variability of urban pollution by trace metals in a given city. Technogenic metalliferous aerosols are
\end{abstract}

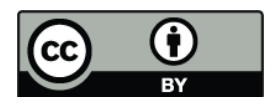

Correspondence to: T. Moreno (teresa.moreno@idaea.csic.es) commonly fine in size and therefore potentially bioavailable, emphasising the case for basing urban background PM characterisation not only on physical parameters such as mass but also on sample chemistry and with special emphasis on trace metal content.

\section{Introduction}

It is by now well established that high concentrations of airborne particulate matter have negative effects on human health (US EPA, 2009 and references therein), this evidence having led to a revision of the WHO Air Quality Guidelines and increasingly worldwide imposition of mandatory limits for $\mathrm{PM}_{10}$ concentrations in the air we breathe (WHO, 2000; Council Directive 2008/50/EC; US EPA, 2004; Moreno et al., 2007). However there is still no common agreement on which size fraction (which will determine its deposition pattern in the respiratory tract) of such particles is causing most damage and likewise which chemical components are most implicated in harmful bioreactions. Key suspects among such chemical components are trace metals which, although low in mass concentration, are ubiquitous in our urban environments, and are thought to play an important role in human health problems due to their commonly high bioreactivity (e.g. Gavett et al., 2003; Schaumann et al., 2004; Valko et al., 2005; Guastadisegni et al., 2010).

Although the presence of trace metals in ambient air is due in part to emissions directly from natural processes such as volcanic eruptions, dust storms or rock weathering, most metalliferous particles are anthropogenic in origin. For example, $\mathrm{V}, \mathrm{Ni}, \mathrm{Co}, \mathrm{Sb}, \mathrm{Cr}, \mathrm{Fe}, \mathrm{Mn}, \mathrm{Cu}, \mathrm{Zn}, \mathrm{As}$ and $\mathrm{Sn}$ are emitted to the atmosphere by fossil hydrocarbon combustion and

Published by Copernicus Publications on behalf of the European Geosciences Union. 
metallurgical industrial activity (e.g. Pacyna, 1986; Querol et al., 2002; Lin et al., 2005; Alastuey et al., 2005), and traffic pollution involves a wide range of trace element emissions that include $\mathrm{Ba}, \mathrm{Pb}, \mathrm{Cu}, \mathrm{Cr}, \mathrm{Sn}, \mathrm{Sb}$ and $\mathrm{Zr}$ (e.g. Pacyna, 1986; Birmili et al., 2006; Amato et al., 2009a; Bukowiecki, et al., 2010). Although all of these metals are typically present in elevated concentrations in the urban atmosphere, only a very few of them are legislated. The European Union for example has set annual limits for $\mathrm{Pb}\left(500 \mathrm{ng} \mathrm{m}^{-3}\right.$; 2008/50/CE), and target values for As $\left(6 \mathrm{ng} \mathrm{m}^{-3}\right), \mathrm{Ni}\left(20 \mathrm{ng} \mathrm{m}^{-3}\right)$ and $\mathrm{Cd}$ $\left(5 \mathrm{ng} \mathrm{m}^{-3}\right)(2004 / 107 / \mathrm{CE})$, whereas the WHO has published guideline values for $\mathrm{Cd}\left(5 \mathrm{ng} \mathrm{m}^{-3}\right), \mathrm{Mn}\left(150 \mathrm{ng} \mathrm{m}^{-3}\right), \mathrm{Pb}$ (500 $\mathrm{ng} \mathrm{m}^{-3}$ ) and $\mathrm{V}\left(1000 \mathrm{ng} \mathrm{m}^{-3}\right.$, daily values).

Atmospheric metalliferous particles are often preferentially concentrated in the finer fractions of particulate matter $\left(\mathrm{PM}_{2.5}\right.$ and $\left.\mathrm{PM}_{1}\right)$, tending to occur in sizes below $1 \mu \mathrm{m}$ (Milford and Davidson, 1985; Utsunomiya et al., 2004; Birmili et al., 2006; Pérez et al., 2008), which not only results in large surface areas being available for reaction with human fluids, but also makes them able to be transported over distances of hundreds of kilometres. Thus air pollutants generated in urban environments can travel to remote and rural areas, increasing the concentration of metal airborne particles in otherwise clean environments (e.g. Harrison and Williams, 1982; Pakkanen et al., 2001; Azimi et al., 2003; Ledoux et al., 2006; Shah et al., 2006). The transport of such metalliferous particles will depend on a series of factors including the atmospheric and weather conditions (humidity, rain scavenging potential, wind direction and wind speed, re-circulation of air masses, dispersive atmospheric conditions), the geography of the area (proximity to the coast, topography, type of soil cover), the season of the year and time of the day (affecting the emissions of specific metals depending on the source intensity), and the size and even morphology of the particles themselves that can favour the resuspension and transport of the particle.

The primary aim of the work presented here is to improve our understanding of the variations in inhalable metalliferous airborne particle concentrations in time and space between major cities and surrounding rural areas. To do this we use a very large database of more than 600 full chemical analyses involving different inhalable size fractions on $12 \mathrm{~h}$ samples collected during both winter and summer. In addition, for the winter data we also obtained hourly concentrations of metals. The results of this study are part of the DAURE (Determination of the sources of atmospheric Aerosols in Urban and Rural Environments in the Western Mediterranean; http://tinyurl.com/daure09) project, the campaign fieldwork for which was carried out during 2009 (Pandolfi et al., 2011b) with the purpose of collecting aerosol measurements simultaneously at an urban site in Barcelona (NE Spain) and Montseny, a relatively remote site high in the Catalan Coastal Ranges (CCR) NNE of the city.

\section{Methodology}

\subsection{Sites description}

The urban nucleus of the city of Barcelona has 1621537 inhabitants (INE 2009), making it the second most populated city in Spain and the tenth within the European Union, with a density of $15991 \mathrm{hab} \mathrm{km}^{-2}$. The city is located in the NE of the Iberian Peninsula, narrowly constricted between the Mediterranean and the CCR (Fig. 1) which help protect the city from the more severe continental weather conditions typical of inland Catalonia, but they also reduce the advective effects of cleansing, Atlanticderived air masses. Along its northern and southern margins the city is delimited by the Llobregat and Besòs river valleys that canalise the winds and also contain important linear concentrations of industrial activity and road transport lines. The selected urban background measurement site in Barcelona (BCN) was located in the southwestern side of the city $\left(41^{\circ} 23^{\prime} 24.01^{\prime \prime} \mathrm{N}, 02^{\circ} 6^{\prime} 58.06^{\prime \prime} \mathrm{E}, 80 \mathrm{~m}\right.$ a.s.l. $)$, at about $500 \mathrm{~m}$ away from the Diagonal Avenue, which is one of the main highways ( $>100000$ vehicles per day) feeding traffic through the city.

Given the distinctive geography of the area, the transport and dispersion of atmospheric pollutants within $\mathrm{BCN}$ are controlled mainly by fluctuating thermally driven coastal winds which typically blow in from the sea during the day (sea breeze) and, less strongly, from the land during the night (mountain breeze). This atmospheric dynamic and the geographic setting have the potential to produce high concentrations of locally derived pollutants within the city. In addition, the activation of up-slope winds combined with the sea breeze (Pérez et al., 2008; Jorba et al., 2011) promotes the transport of pollution from the city and its surrounding industrial areas (including emissions from road and marine traffic, and industrial, agricultural and power generation activities) along the NE-SW oriented coastline and inland regional/rural areas. This is well illustrated within Montseny Natural Park where there is a regional background air monitoring station (MSY: $41^{\circ} 46^{\prime} 45.63^{\prime \prime} \mathrm{N} 02^{\circ} 21^{\prime} 28.92^{\prime \prime} \mathrm{E}, 720 \mathrm{~m}$ a.s.l.; $50 \mathrm{~km}$ NW Barcelona) belonging to the Air Quality network of the Autonomous Government of Catalonia. This monitoring site is also included in the EUSAAR (European Supersites for Atmospheric Aerosol research) network and is known to be liable to contamination, depending on atmospheric conditions, from the urban pollution plume emanating from Barcelona (Pérez et al., 2008; Pey et al., 2010a).

Existing data on $\mathrm{PM}_{10}$ levels over the last $10 \mathrm{yr}$ in the city of Barcelona show levels for urban background sites varying from $28-42 \mu \mathrm{gPM}_{10} \mathrm{~m}^{-3}, 18-27 \mu \mathrm{gPM}_{2.5} \mathrm{~m}^{-3}$, and 13-20 $\mu \mathrm{gPM}_{1} \mathrm{~m}^{-3}$, but these levels increase up to 39$55 \mu \mathrm{gPM}_{10} \mathrm{~m}^{-3}$ in traffic hot spot sites, or in specific industrial areas with higher contamination (updated from Querol et al., 2008). Given the geographically confined nature of the city, and the paucity of central urban green spaces, 
urban background levels breathed by the local population are strongly contaminated by vehicle emissions. In addition to locally sourced air pollution, a further contribution to ambient PM concentrations in Barcelona is frequently made by the arrival of dusty air masses from the Sahara and Sahel desert regions of North Africa (e.g. Rodríguez et al., 2001; Moreno et al., 2006; Pérez et al., 2008; Querol et al., 2009). This contribution is estimated as directly adding around $1-2 \mu \mathrm{gPM}_{10} \mathrm{~m}^{-3}$ and $0.2-1 \mu \mathrm{g} \mathrm{PM}_{2.5} \mathrm{~m}^{-3}$ to annual averages in the city (Escudero et al., 2007), as well as being responsible for $10-20$ of the annual daily limit value exceedances (23-27\% of total exceedances). Considering, however, that the total mineral contribution to $\mathrm{PM}_{10}$ mass in Barcelona averages around $8-16 \mu \mathrm{g} \mathrm{m}^{-3}$, it becomes obvious that African dust intrusions per se are not the primary direct source of mineral aerosols in the city air. Most such particles (i.e. 5-15 $\mu \mathrm{gPM}_{10} \mathrm{~m}^{-3}$ ) are in fact anthropogenic in origin, in the sense that, although being natural materials derived from rocks and soils (mostly felsic silicates and calcium carbonate) they are released into the atmosphere by resuspension from moving traffic, pavement abrasion, construction/demolition work and other human activities (Amato et al., 2009a).

A description of the mesoscale and local meteorological processes affecting both BCN and MSY sites is provided in Pey et al. (2010b) and Pandolfi et al. (2011b). Whereas Barcelona pollution is dominated by local anthropogenic emission sources, at Montseny the particulate matter composition is mainly related to meteorological controls. Thus during summer, due to the predominance of high pressure and high insolation, air pollutants are concentrated by lo$\mathrm{cal} /$ regional circulations at different altitudes in the atmosphere (Rodríguez et al., 2002, 2003). In contrast, during winter the advection of air masses from the Atlantic is favoured by the location of the Azores anticyclone, thus reducing levels of pollutants in the area. Nevertheless, pollution episodes related with strong anticyclonic conditions are frequently observed in winter, increasing the levels of pollutants at a regional scale (Pey et al., 2010a). In addition breeze patterns also play an important role in the transport of contaminants from the urban to the rural sites. In Barcelona the sea breeze develops around 10:00 UTC, reducing especially $\mathrm{PM}_{1}$ concentrations in the city, whereas levels increase after 18:00 UTC when the mountain breeze starts bringing pollution in from the surrounding industrial valleys and the wider metropolis around the city centre. In the hills of Montseny the opposite is the case, with the finer PM fraction tending to increase during the daytime due to the outcoming sea breeze bringing contaminants from Barcelona, and decrease during the evening (Pérez et al., 2008; Pey et al., 2010b).

Measurements and sampling of aerosols during the DAURE campaign were simultaneously conducted at both sites, BCN and MSY, during winter (February-March 2009) and summer (July 2009). Three generalised atmospheric scenarios have been described during the winter campaign, one

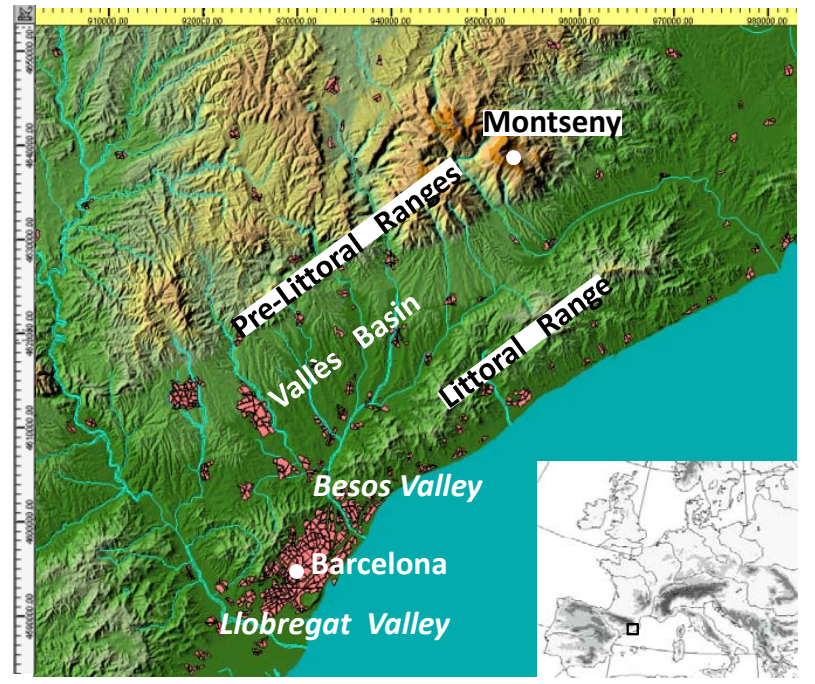

Fig. 1. Location map of both monitoring sites, Barcelona and Montseny; indicating the main topographic features that influence the air pollutant concentrations and transport. The major coastal city of Barcelona is confined between the Mediterranean Sea and the Littoral Range. The urban pollution plume commonly moves from the coast into the Vallès Basin, contaminating the hinterland of the Pre-Littoral Ranges where the remote Montseny monitoring site is located.

being characterised by cleansing Atlantic-derived advective winds, and the others involving increasing air pollution under the stagnating influence of anticyclonic conditions and differing only in whether MSY lay within or above the atmospheric boundary layer (ABL). Regarding summer conditions, these were mainly differentiated into regional pollution scenarios involving recirculation of polluted air masses at regional scale (with MSY always lying within the ABL during the day), Atlantic advections, and the presence of air masses from the African continent (Pandolfi et al., 2011b).

\subsection{Sample collection and analysis}

Two sampling campaigns were run in order to investigate the differences between summer and winter pollution scenarios at both urban and rural sites. Each campaign lasted for a whole month, taking place on February-March and July 2009. For better understanding Table 1 lists measurements (time resolution and PM size fraction) carried out during the campaigns. Data were obtained using gravimetric $\mathrm{PM}_{10}, \mathrm{PM}_{2.5}$ and $\mathrm{PM}_{1}$ high-volume instruments at a flow of $30 \mathrm{~m}^{3} \mathrm{~h}^{-1}$ (MCV-CAV and DIGITEL-DH80), that were continuously sampling at each site (BCN and MSY) during periods of $12 \mathrm{~h}$ (09:00-21:00 and 21:00-09:00 UTC), with the exception of the $\mathrm{PM}_{1}$ fraction during the summer campaign when only $24 \mathrm{~h}$ filters were collected at both sites. A total of 630 samples were collected on quartz fibre filters (Munktell MK360 for the winter and Pall 2500QAT-UP 
Table 1. Frequency and time resolution of measurements carried out during winter and summer campaigns at both Barcelona (BCN) and Montseny (MSY) sites.

\begin{tabular}{llllll}
\hline & & \multicolumn{2}{c}{ Winter } & \multicolumn{2}{c}{ Summer } \\
& & BCN & MSY & BCN & MSY \\
\hline \multirow{4}{*}{ High Volume } & $\mathrm{PM}_{10}$ & $12 \mathrm{~h}$ & $12 \mathrm{~h}$ & $12 \mathrm{~h}$ & $12 \mathrm{~h}$ \\
& $\mathrm{PM}_{2.5}$ & $12 \mathrm{~h}$ & $12 \mathrm{~h}$ & $12 \mathrm{~h}$ & $12 \mathrm{~h}$ \\
& $\mathrm{PM}_{1}$ & $12 \mathrm{~h}$ & $12 \mathrm{~h}$ & $24 \mathrm{~h}$ & $24 \mathrm{~h}$ \\
\hline \multirow{5}{*}{ Drum Impactor } & $\mathrm{PM}_{2.5-10}$ & $1 \mathrm{~h}$ & $2 \mathrm{~h}$ & & \\
& $\mathrm{PM}_{1-2.5}$ & $1 \mathrm{~h}$ & $2 \mathrm{~h}$ & & \\
& $\mathrm{PM}_{0.1-1}$ & $1 \mathrm{~h}$ & $2 \mathrm{~h}$ & & \\
\hline
\end{tabular}

for the summer campaigns respectively, $150 \mathrm{~mm}$ ) previously pre-heated at $200^{\circ} \mathrm{C}$ during $4 \mathrm{~h}$, conditioned at $20-25^{\circ} \mathrm{C}$ and $25-30 \%$ of relative humidity during at least $24 \mathrm{~h}$, and subsequently weighed three times on different days. After sampling, the filters were conditioned again and weighed as previously described. Once the gravimetric determination was performed the filters were treated and analyzed for the determination of the chemical composition of PM. For this, one quarter of each filter was acid digested ( $\left.\mathrm{HF}: \mathrm{HNO}_{3}: \mathrm{HClO}_{4}\right)$, kept at $90{ }^{\circ} \mathrm{C}$ in a Teflon reactor during $6 \mathrm{~h}$, driven to dryness and re-dissolved with $\mathrm{HNO}_{3}$ to make up a volume of $25 \mathrm{ml}$ with bidistillated water, for chemical analysis using Inductively Coupled Plasma Atomic Emission Spectrometry for the determination of the major elements (ICP-AES: IRIS Advantage TJA Solutions, THERMO) and Mass Spectrometry for the trace elements (ICP-MS: X Series II, THERMO). To assure the quality of the analytical procedure a small amount $(15 \mathrm{mg}$ ) of the NIST-1633b (fly ash) reference material loaded on a $1 / 4$ quartz micro-fibre filter was also analysed, these reaching values $<10 \%$ for all trace elements. The rest of each filter was kept for the determination of soluble ion concentrations, the analysis of organic and elemental carbon and the determination of levoglucosan and dicarboxylic acids, which are not dealt with in this manuscript as they are described in other works from the DAURE campaign.

In addition, elemental characterisation of size-segregated PM was performed with hourly resolution at both urban and rural sites continuously during the winter campaign. To this aim a rotating drum impactor (Bukowiecki et al., 2009; Richard et al., 2010) from the Paul Scherrer Institute (PSI, from Switzerland) was installed to collect hourly aerosol samples in three size ranges $(0.1-1 \mu \mathrm{m}, 1-2.5 \mu \mathrm{m}$ and $2.5-$ $10 \mu \mathrm{m})$. The collected samples were analysed by synchrotron radiation X-Ray fluorescence spectrometry (SR-XRF, see Bukowiecki et al. (2009) for details).

Different techniques of PM sampling and elemental characterization can easily lead to bias in results. The off-line determination of the trace elements concentrations is the final result of a number of processes that are affected by un- certainty. The main sources of uncertainty are the deviation from the cut-off standards, the error in air volume determination, positive and negative artefacts, weighing, efficiency of analytical procedure, blank subtraction, etc. These factors can be more relevant for one methodology with respect to another, therefore caution must be paid when comparing simultaneous results from different techniques.

In our study we compare the uncorrected concentrations obtained by means of the 2hDRUM+SXRF and 12hFilters+ICPMS approaches. To this aim, the 1 and $2 \mathrm{~h}$ concentrations of DRUM+SXRF were averaged into $12 \mathrm{~h}$ intervals to match with corresponding sampling of $12 \mathrm{hFilters+ICPMS}$. When analyzing separately the different PM sizes, more sources of uncertainty are present. On the one hand, the DRUM sampling does not collect particles $<100 \mathrm{~nm}$, on the other hand the ICPMS concentrations for $\mathrm{PM}_{1-2.5}$ and $\mathrm{PM}_{2.5-10}$ are calculated as differences between the $\mathrm{PM}_{1}, \mathrm{PM}_{2.5}$ and $\mathrm{PM}_{10}$ samples. Similarly the DRUM concentrations for $\mathrm{PM}_{10}$ were calculated as the sum of the three PM fractions, thus propagation of errors must be taken into account.

In absolute terms, the $\mathrm{PM}_{10}$ concentrations showed a general agreement (difference within $\pm 40 \%$ ) between the two techniques for metals such as $\mathrm{Ti}, \mathrm{Mn}, \mathrm{V}, \mathrm{Cu}, \mathrm{Zn}, \mathrm{Sn}$ and $\mathrm{Sb}$. Only for $\mathrm{Ni}$, concentrations were significantly different (ratio $\mathrm{ICP} / \mathrm{SXRF}=0.3$ ) (Fig. 2). Several elements (Ti, V, Ni, $\mathrm{Cu}$ and $\mathrm{Sn}$ ) in the $\mathrm{PM}_{0.1-1}$ showed much lower concentrations by SXRF when compared to ICPMS $\left(\mathrm{PM}_{1}\right)$. Conversely more agreement was found for the coarser fractions $\left(\mathrm{PM}_{1-2.5}\right.$ and $\mathrm{PM}_{2.5-10}$ ). In all cases correction factors were applied in order to compare the Barcelona and Montseny sites.

Meteorological variables including atmospheric pressure, wind direction and speed, solar radiation, temperature and relative humidity were provided from a nearby meteorological station by the Faculty of Physics from Barcelona University (in the case of the urban site in $\mathrm{BCN}$ ) and a meteorological station located in the monitoring site (in the case of the rural site at MSY).

\section{Results}

\subsection{Metal enrichments and seasonal variations}

Normalising average metal values of our atmospheric PM samples against those for average upper continental crust (ppm metal in sample/ppm metal in UCC) (Wedepohl, 1995) reveals the extent of atmospheric enrichment in technogenic elements associated with traffic and industrial emissions. Examples of these pollution markers are illustrated in Fig. 3 where $\mathrm{V}, \mathrm{Pb}, \mathrm{Cu}, \mathrm{Zn}, \mathrm{Mn}, \mathrm{Sn}, \mathrm{Bi}, \mathrm{Sb}$ and $\mathrm{Cd}$ all show UCC normalised values $>1$, in broadly increasing order, a technogenic enrichment which contrasts with "crustal" elements such as $\mathrm{Rb}$ and $\mathrm{Sr}$ which are depleted in the atmosphere relative to their UCC concentrations. Figure 3 also illustrates 


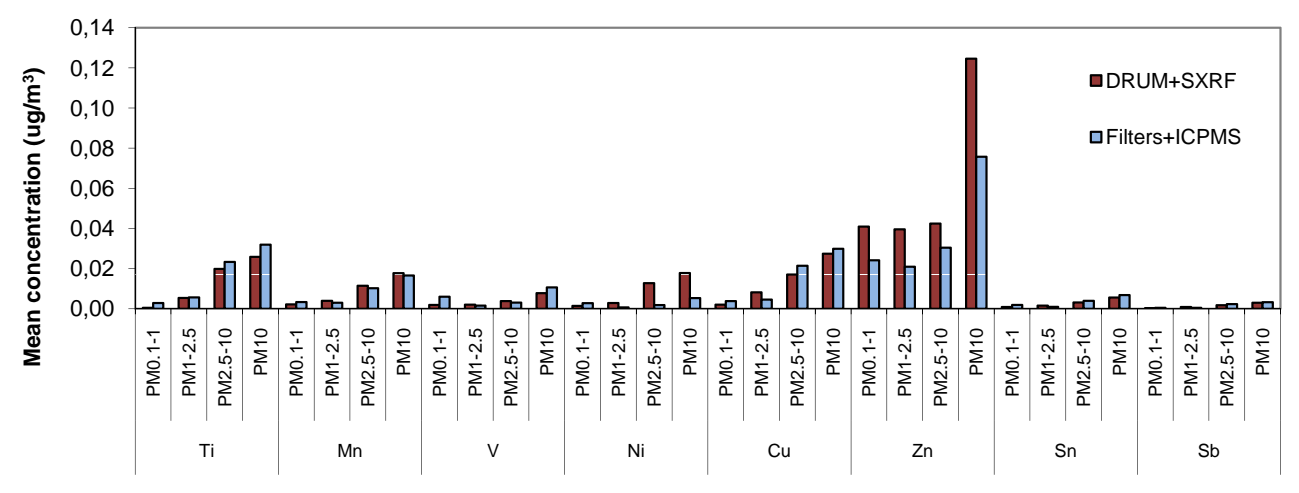

Fig. 2. Comparison of elemental concentrations obtained by ICP and SXRF techniques during the winter campaign at both BCN and MSY sites.

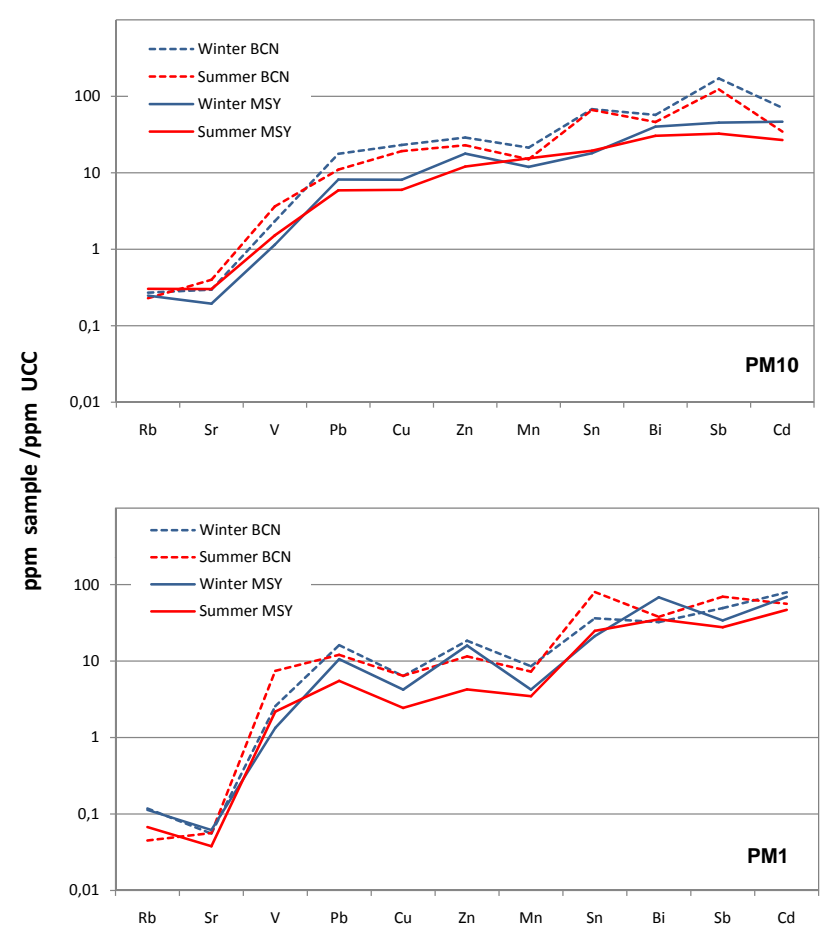

Fig. 3. Average metal values of $B C N$ and $M S Y$ atmospheric $P_{10}$ and $\mathrm{PM}_{1}$ samples normalised to the average concentrations in the upper continental crust (UCC) (Wedepohl, 1995). Only the nine most technogenic metals (ratio $>1$ ) are shown, plus for comparison $\mathrm{Rb}$ and $\mathrm{Sr}$ which represent more "crustal" PM sources.

key seasonal differences between $\mathrm{PM}_{10}$ normalised levels at the two monitoring sites. The metal enriched nature of the summer air in MSY as compared to winter is apparent in the case of V, Mn and Sn, whereas at BCN, with the exception of $\mathrm{V}$ (and Ni, see Table 2), the technogenic pollutants are always present in higher average relative enrichments during winter. A similar pattern is shown by the finest $\mathrm{PM}_{1}$ fraction in which most elements (except again $\mathrm{V}$ and $\mathrm{Sn}$ ) show higher winter concentrations at MSY as well as BCN (Table 2, Fig. 3).

The variations in average elemental concentrations during summer and winter campaigns at both sites are emphasised in Table 2 (highest levels in bold). These data confirm how most of the highest levels recorded for individual elements (both average and maxima) occurred either during the winter at BCN or during the summer at MSY. Thus in the case of the $\mathrm{PM}_{10}$ filters collected during the $\mathrm{BCN}$ winter, these show highest average concentrations of $\mathrm{Zn}\left(81 \mathrm{ng} \mathrm{m}^{-3}\right), \mathrm{Cu}$ $\left(27 \mathrm{ng} \mathrm{m}^{-3}\right), \mathrm{Sn}\left(6 \mathrm{ng} \mathrm{m}^{-3}\right), \mathrm{Sb}\left(3 \mathrm{ng} \mathrm{m}^{-3}\right), \mathrm{Tl}\left(0.4 \mathrm{ng} \mathrm{m}^{-3}\right)$, $\mathrm{Pb}\left(13 \mathrm{ng} \mathrm{m}^{-3}\right)$ and $\mathrm{Bi}\left(0.4 \mathrm{ng} \mathrm{m}^{-3}\right)$. The contrasting exceptions of $\mathrm{V}$ and $\mathrm{Ni}$ at the $\mathrm{BCN}$ site registered highest average concentrations in summer $\left(13 \mathrm{ng} \mathrm{m}^{-3}\right.$ and $6 \mathrm{ng} \mathrm{m}^{-3}$ respectively) rather than winter $\left(9 \mathrm{ng} \mathrm{m}^{-3}\right.$ and $5 \mathrm{ng} \mathrm{m}^{-3}$ respectively). In the case of the finer fractions $\left(\mathrm{PM}_{2.5}\right.$ and $\left.\mathrm{PM}_{1}\right)$, once again the $\mathrm{BCN}$ winter samples were far more metalliferous, with $\mathrm{PM}_{2.5}$ highs in $\mathrm{Cu}, \mathrm{Zn}, \mathrm{As}, \mathrm{Rb}, \mathrm{Cd}, \mathrm{Sb}, \mathrm{Ta}, \mathrm{Tl}$, $\mathrm{Pb}$ and $\mathrm{Bi}$ and $\mathrm{PM}_{1}$ maxima in the majority of trace elements (Table 2). Only V, Ni, Co and $\mathrm{Sb}$ registered $\mathrm{BCN}$ maxima in the averages for summer $\mathrm{PM}_{1}$ (Table 2).

Average $\mathrm{PM}_{10}$ and $\mathrm{PM}_{1}$ trace metal concentrations during summer and winter at both sites are shown in Fig. 4. At the MSY site, the differences between the two campaigns are generally smaller than in BCN. However, for both MSY $\mathrm{PM}_{10}$ and $\mathrm{PM}_{2.5}$ there were lower levels of most metals during winter (except for $\mathrm{Cr}, \mathrm{Cu}, \mathrm{Zn}, \mathrm{Cd}, \mathrm{Sb}$, and $\mathrm{Pb}$ ) whereas in summer the average concentrations of some elements in these PM size fractions can climb to levels exceeding even those in Barcelona city (Ti and Rare Earth Elements - REE). The distribution of metals in the finest fraction measured at MSY $\left(\mathrm{PM}_{1}\right)$ is quite different, despite the same mass levels, with the winter PM being generally much more metalliferous and showing campaign maxima for average levels of $\mathrm{Ti}, \mathrm{Cr}$, $\mathrm{Zr}$, Hf, REE, W, and Bi (Fig. 4). Other metals such as Mn, $\mathrm{Co}, \mathrm{Ni}, \mathrm{As}$ and $\mathrm{Sb}$ were very similar during both campaigns, with only MSY V and Sn having average $\mathrm{PM}_{1}$ concentrations higher in summer than winter, as previously shown by 


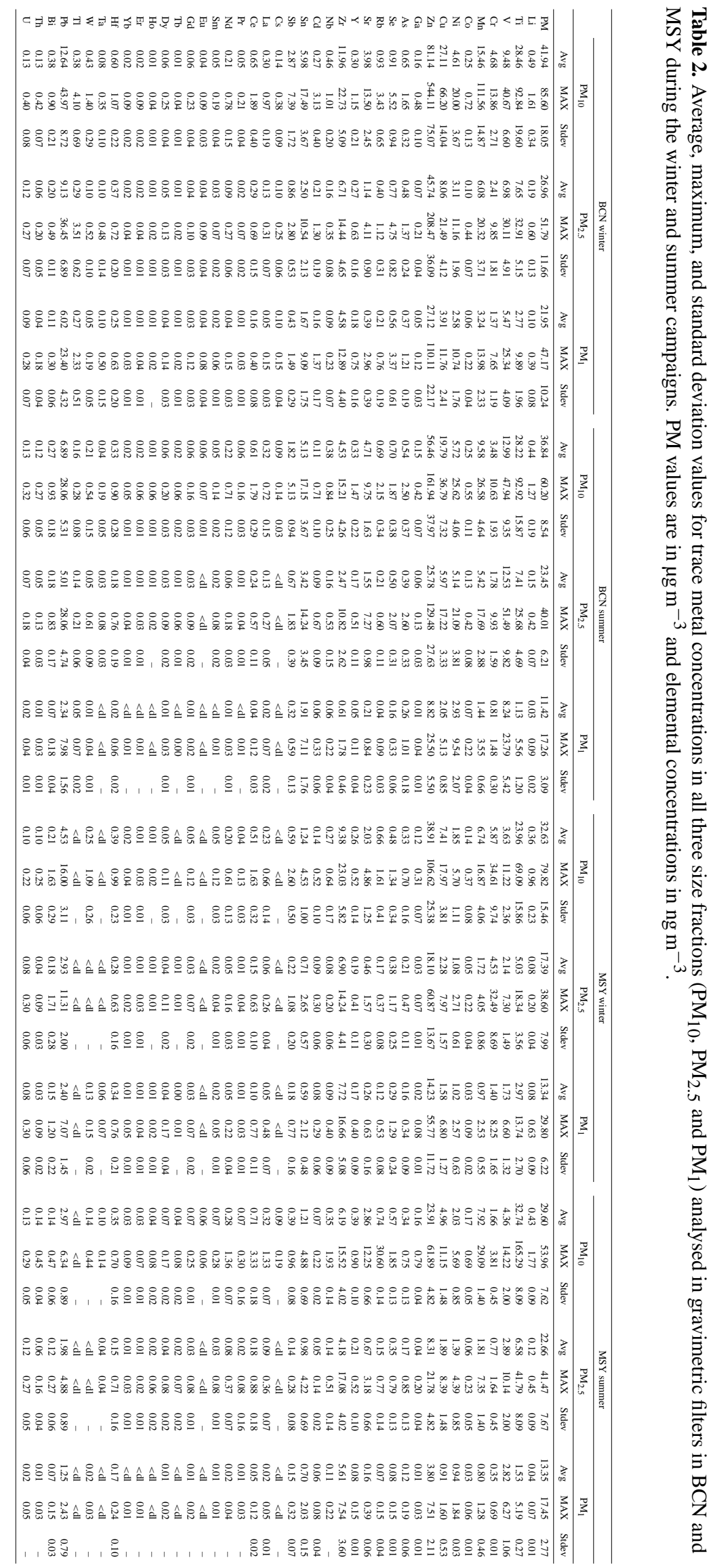



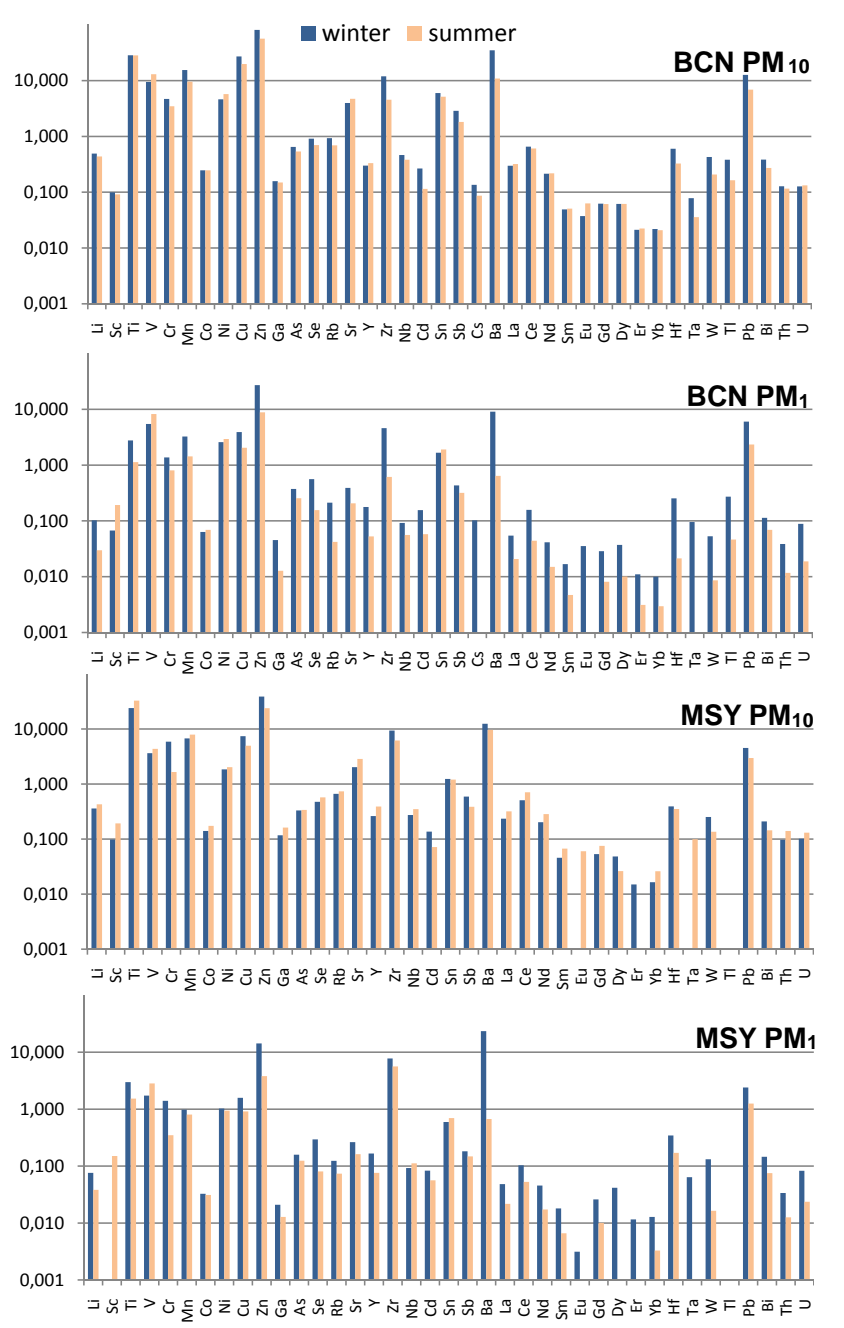

Fig. 4. Average $\mathrm{PM}_{10}$ and $\mathrm{PM}_{1}$ trace metal concentrations at the $\mathrm{BCN}$ and MSY sites for both summer and winter campaigns (ng $\mathrm{m}^{-3}$ ). In BCN $\mathrm{PM}_{10}$ metal concentrations were clearly higher during winter, while differences between campaigns were smaller in MSY (with $\mathrm{PM}_{10}$ showing lower levels of most metals during winter). Whereas in $\mathrm{BCN}$ same pattern was observed in the $\mathrm{PM}_{1}$ size fraction, the distribution of metals in this fraction at MSY was however quite different, with the winter PM being generally much more metalliferous.

their relative enrichment respect to UCC levels.

With regard to relative abundance, in $\mathrm{BCN} \mathrm{Zn}>\mathrm{Ti}>\mathrm{Cu}$ were the three most common metals in both winter (all in concentrations $>27 \mathrm{ngPM}_{10} \mathrm{~m}^{-3}$ ) and summer (all $>19 \mathrm{ngPM}_{10} \mathrm{~m}^{-3}$ ) filter samples, followed by $\mathrm{Mn}, \mathrm{Pb}, \mathrm{Zr}$ and V. In the case of MSY Zn and Ti were again all dominant metals in both winter and summer $\mathrm{PM}_{10}$ fractions (both $\left.>20 \mathrm{ng} \mathrm{m}^{-3}\right)$. Average levels of those metals regulated by the EU ( $\mathrm{As}, \mathrm{Cd}, \mathrm{Ni}, \mathrm{Pb}$ ) did not exceed the annual limit target concentrations. Highest average levels of most of these toxic metals/metalloids in $\mathrm{PM}_{10}$ were recorded in the win- ter data collected from $\mathrm{BCN}$ monitoring station as expected, with the exception of $\mathrm{Ni}$ that was higher in summer (Table 2).

We also observe notable variations in metal concentrations between daytime (09:00-21:00 UTC) and night-time (21:0009:00 UTC) as shown in Table 3. At both BCN and MSY sites daytime samples contain higher concentrations of most metals compared to those collected at night, this presumably reflecting the inclusion of both morning and evening traffic rush hour periods in the daytime samples. Such daytime enrichment of airborne metals is especially marked in the MSY winter data where levels of many metals such as $\mathrm{Ti}, \mathrm{Mn}, \mathrm{Cu}$, $\mathrm{Sn}, \mathrm{Sb}$, and REE are around double those during the night as a consequence of the transport of polluted air masses in the afternoon driven by the sea breeze. The notable exception to this general rule, and in contrast to MSY, is that in all $\mathrm{BCN}$ samples average concentrations of $\mathrm{Cu}, \mathrm{Zn}, \mathrm{As}$ and $\mathrm{Pb}$ show night enrichments. This differing behaviour of these four transition elements occurs in both winter and summer, and is also shown by $\mathrm{Cr}$ and $\mathrm{Sb}$ during the summer only (Table 3). In the case of MSY only $\mathrm{Cr}$ and finest $\mathrm{Ti}$, La and Ce were richer during the winter nights, whereas in summer $\mathrm{PM}_{2.5}$ night-time samples were slightly more metalliferous than during the day ( $\mathrm{Ti}, \mathrm{Cr}, \mathrm{Ni}, \mathrm{Rb}, \mathrm{Sr}, \mathrm{REE}$ ).

Comparison of average concentration values of metals during this campaign with data from previous continuous measurements in urban background sites in BCN and at MSY (Amato et al., 2009b; Pey et al., 2009) shows variable results. Thus in the case of BCN only V during the DAURE summer campaign was higher than previously analysed (for all three size fractions, Amato et al., 2009), whereas in MSY some metals including $\mathrm{Li}, \mathrm{V}, \mathrm{Cr}, \mathrm{Mn}, \mathrm{Ni}, \mathrm{Cu}, \mathrm{Zn}, \mathrm{Sr}$ and $\mathrm{Sn}$ were slightly higher during both DAURE samplings. Although in the latter case the enhanced concentrations were only obvious in the coarse $\mathrm{PM}_{10}$ fraction.

\subsection{Hourly variations in airborne metal concentrations}

Daily cycles of metal concentrations were revealed by the rotating drum impactor data collecting hourly samples in three different PM size fractions $(0.1-1,1-2.5$ and $2.5-10 \mu \mathrm{m})$ at both BCN and MSY during the winter campaign. There are striking differences in the variation patterns of average concentrations shown by trace metals at the BCN site. Thus although these hourly concentrations showed in some cases a wide range of values (Fig. 5), which were in all cases related to specific pollution events (discussed later in Sect. 3.4 in more detail). Some metals (notably $\mathrm{Cu}, \mathrm{Sb}$, and also $\mathrm{Sn}, \mathrm{Ba}$ ) record two peaks during the day (07:00-08:00 and 20:00-21:00 UTC) whereas others (Ni, and also $\mathrm{Mn}, \mathrm{Cr})$ show only a morning peak (08:00-09:00 UTC) (Fig. 6a, b, c). The "double peak" metal pattern in BCN is attributed to the influence of a traffic source more than to the atmospheric boundary layer variations as only these specific metals show it, reaching maximum levels at rush-hours in the morning and evening. It is notable that this double peak pattern is 


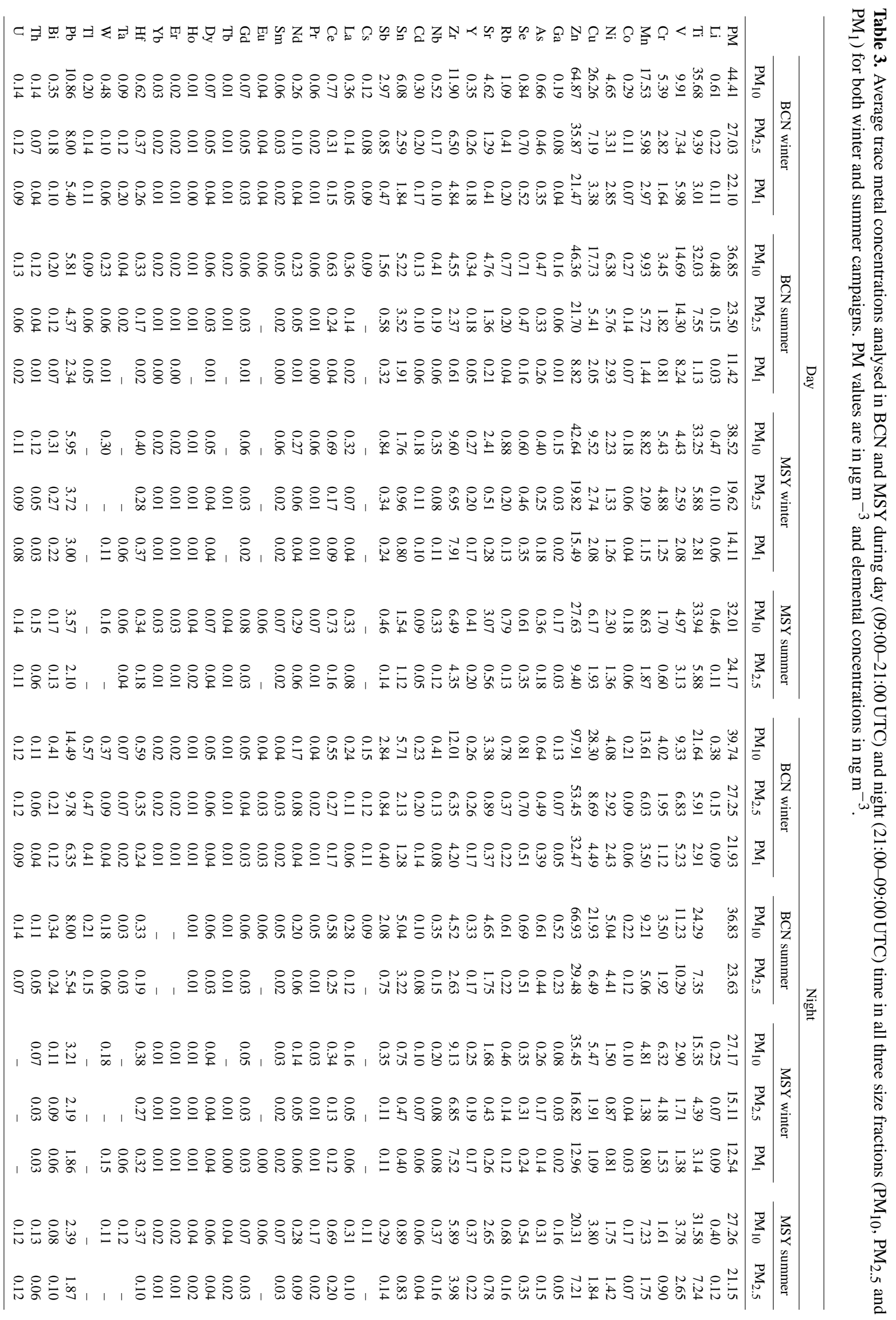



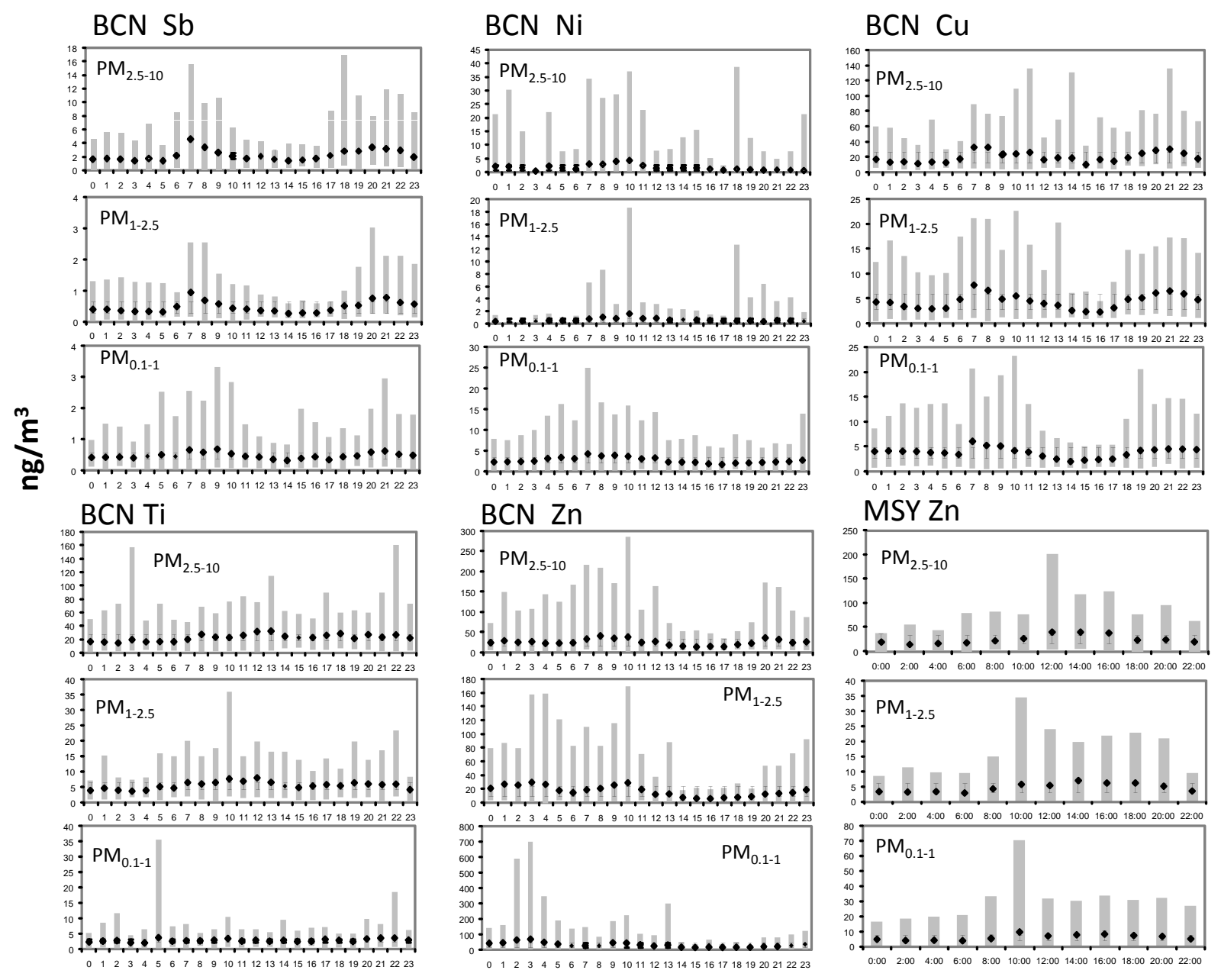

Fig. 5. Average (black rhombus) and range of hourly concentrations (horizontal axe) obtained for each PM fraction of specific metals (see Fig. 6) using SXRF.

particularly well displayed by the coarser PM fraction, indicating the presence of PM from mechanical abrasion and road dust resuspension processes. This is well illustrated by elements such as $\mathrm{Sb}$ and $\mathrm{Cu}$, classic road traffic trace metal markers, which show strong $\mathrm{PM}_{10}$ peaks but little daily variation in the $\mathrm{PM}_{1}$ size fraction (Fig. 6a, b).

The "single morning peak" metal group identified during the winter campaign at $\mathrm{BCN}$ is particularly well displayed by $\mathrm{Ni}$ (Fig. 6c), and also Cr, and is attributed mostly to industrial metallurgical emissions. These metals, together with $\mathrm{Mn}$ and $\mathrm{Fe}$, contribute to the winter morning industrial pollution plumes driven seaward overnight by land breezes channelled along the Llobregat River, which delimits the western side of Barcelona (Fig. 1; Pey et al., 2010b; Pandolfi et al., 2011b). Reversal of wind direction, as the morning sea breezes begin, can result in the advection of this contaminated air into the city before daytime dilution and dispersal of the metals occur within the expanding mixing layer. A similar pattern can also be observed in some metals due to the breeze patterns in the Llobregat Basin. The land breeze coming down into $\mathrm{BCN}$ in the first hours of the day is responsible for high concentrations of industrial metals such as Zn (Fig. 6d) and $\mathrm{Pb}$, this being especially pronounced in the case of the finer particles. During the afternoon the cleansing effect of the sea breeze within the urban atmosphere is evidenced by the reduction in the concentration of most metals, showing levels similar to those measured during the night, maybe also influenced by the lower intensity in the industrial activities. The results from MSY are different from any pattern identified at BCN. For most metals there is a single metalliferous peak rising in the mid-morning to a midday-afternoon high before declining in the late afternoon (Fig. 6e). Despite the relatively unpolluted nature of the MSY site during winter, it is clear that the area was being contaminated by the daytime arrival of technogenic pollution peaking during the afternoon as shown by the daytime chemical analysis (Table 3). The same pattern of an afternoon peak value was shown for all three size fractions. Finally, several of the more "crustal" elements, such as $\mathrm{Ti}, \mathrm{Zr}, \mathrm{Sr}$ and $\mathrm{Rb}$, do not conform to either pollution pattern outlined above. These metals increase in 

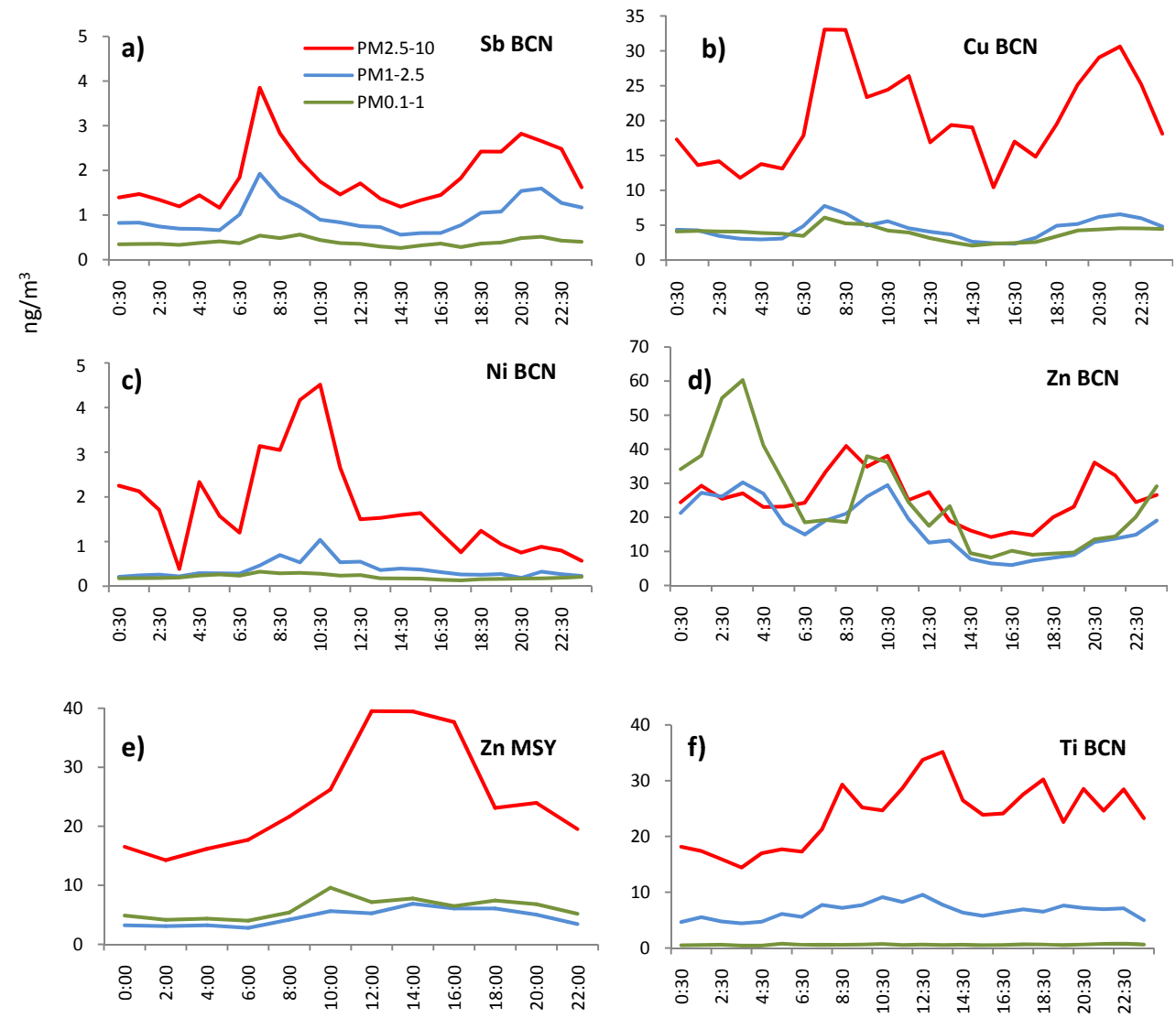

Fig. 6. Different daily cycles of metal concentrations from hourly levels recorded by the rotating drum impactor in three different PM size fractions (0.1-1, 1-2.5 and 2.5-10 $\mu \mathrm{m}$ ) during the winter campaign. (a) Sb in Barcelona (mainly traffic); (b) Cu in Barcelona (mainly traffic); (c) Ni in Barcelona (mainly industrial); (d) Zn in Barcelona (traffic and industry); (e) Zn in Montseny (traffic and industry); (f) Ti in Barcelona (mainly crustal).

overall concentration during the day, but without displaying obvious peaks (Fig. 6f). Their presence in the ambient urban atmosphere is attributed partly to resuspension processes such as traffic movement but especially to ubiquitous construction activity that was taking place during the campaign (Amato et al., 2011; Reche et al., 2011). Pearson correlation coefficients among trace metals, for each of the considered PM fractions hourly measured at $\mathrm{BCN}$, show values $>0.7$ in $\mathrm{PM}_{2.5-10}$ and $\mathrm{PM}_{1-2.5}$ fractions for mineral (Ti, $\mathrm{Rb}, \mathrm{Sr}$ ), industrial $(\mathrm{Cr}, \mathrm{Mn}, \mathrm{Ni})$ and road dust components $(\mathrm{Cu}, \mathrm{Sn}, \mathrm{Sb}$, $\mathrm{Co}$ ), whereas in the $\mathrm{PM}_{0.1-1}$ samples the coefficient is only that high for elements related to anthropogenic sources such as $\mathrm{V}-\mathrm{Ni}, \mathrm{Cr}-\mathrm{Sn}, \mathrm{Mn}-\mathrm{Zn}-\mathrm{Pb}, \mathrm{Cu}-\mathrm{Sb}$. In the case of MSY the scenario is more complex as most elements show values $>0.7$ for all 3 fractions, with the exception of $\mathrm{Cr}-\mathrm{Sr}$ in $\mathrm{PM}_{2.5-10}$ and $\mathrm{Cr}-\mathrm{Mn}-\mathrm{Ni}$ in $\mathrm{PM}_{1-2.5}$, indicating a more mixed setting than in the urban environment and the influence of the arrival of such urban pollutants to the site. Such correlation coefficients are in agreement with the daily patterns of those elements described in this section.
A varimax rotated factor analysis was also performed to identify the main sources affecting the PM composition at each sampling site. Chemical species of known origin are frequently used as source tracers. Principal component analysis (PCA) was applied to obtain such emission sources (factors) in our analyses accounting for $62-76 \%$ of the variance of the dataset due to the low number of variables. Results do not differ greatly from those shown by the Pearson correlation coefficients although are obviously more detailed (Table 4). Thus in BCN all three PM size fractions showed a mineral and a traffic source, with an additional industrial source in the coarse PM (Ni, Cr and $\mathrm{Mn})$, whereas 2 industrial factors were identified in the $\mathrm{PM}_{1-2.5}(\mathrm{Ni}, \mathrm{Cr}$ and $\mathrm{Zn}$, $\mathrm{Pb}, \mathrm{V})$ and the $\mathrm{PM}_{0.1-1}(\mathrm{Zn}, \mathrm{Mn}, \mathrm{Pb}$ and $\mathrm{Ti}, \mathrm{V}, \mathrm{Ni})$. In the case of MSY a traffic source was clearly identified only in the coarse PM size, with mineral and industrial $(\mathrm{Pb})$ factors appearing in the two coarser fractions. The $\mathrm{PM}_{0.1-1}$ case is different, as although three main factors were separated by the PCA, all three seem to be mixtures of sources (traffic, mineral and industrial), this supporting the previous results on the more mixed nature of the aerosols in the rural site after being transported from the urban environment. 
Table 4. Main factors identified by Principal Components Analysis for the trace metals analysed in the three size fractions measured at BCN and MSY during the winter campaign. (\%: variance percentage of each factor).

\begin{tabular}{|c|c|c|c|c|c|c|c|c|c|c|c|c|c|c|}
\hline & & \multicolumn{5}{|c|}{$\mathrm{BCN}$} & & & & \multicolumn{5}{|c|}{ MSY } \\
\hline & & Traffic & & Industrial & & Mineral & & & & Mineral & & Traffic & & Industrial \\
\hline \multirow{11}{*}{$\begin{array}{c}0 \\
1 \\
n \\
n \\
\sum_{2}^{i}\end{array}$} & SB & 0.8543 & NI & 0.9622 & $\mathrm{RB}$ & 0.8202 & & & $\mathrm{RB}$ & 0.9093 & $\mathrm{CU}$ & 0.7514 & $\mathrm{~PB}$ & 0.8425 \\
\hline & SN & 0.8312 & CR & 0.6919 & SR & 0.7308 & & & FE & 0.8788 & SB & 0.7351 & & \\
\hline & $\mathrm{CU}$ & 0.7439 & MN & 0.6572 & TI & 0.6709 & & & MN & 0.8459 & SN & 0.6774 & & \\
\hline & FE & 0.7295 & $\mathrm{CO}$ & 0.5587 & FE & 0.4618 & & & $\mathrm{BA}$ & 0.7292 & $\mathrm{ZN}$ & 0.5810 & & \\
\hline & BA & 0.6792 & $\mathrm{FE}$ & 0.4444 & BA & 0.4428 & & & CR & 0.6667 & & & & \\
\hline & $\mathrm{CO}$ & 0.5951 & & & MN & 0.4048 & & & TI & 0.6090 & & & & \\
\hline & $\mathrm{ZN}$ & 0.5553 & & & & & & & ZR & 0.5533 & & & & \\
\hline & $\mathrm{ZR}$ & 0.4905 & & & & & & & $\mathrm{SR}$ & 0.5459 & & & & \\
\hline & & & & & & & & & $\mathrm{ZN}$ & 0.5195 & & & & \\
\hline & $\%$ & 42.8 & & 12.8 & & 6.5 & & & $\%$ & 45.2 & & 9.6 & & 7.5 \\
\hline & & Traffic & & Industrial-1 & & Industrial-2 & & Mineral & & Mineral & & Industrial & & \\
\hline \multirow{14}{*}{$\frac{n}{i}$} & $\mathrm{Sn}$ & 0.9331 & $\mathrm{Ni}$ & 0.9197 & $\mathrm{Zn}$ & 0.8387 & $\mathrm{Sr}$ & 0.8357 & $\mathrm{FE}$ & 0.7882 & PB & 0.8026 & & \\
\hline & $\mathrm{Sb}$ & 0.9104 & $\mathrm{Cr}$ & 0.8793 & $\mathrm{~Pb}$ & 0.7205 & $\mathrm{Rb}$ & 0.8309 & TI & 0.7354 & $\mathrm{BA}$ & 0.7732 & & \\
\hline & $\mathrm{Cu}$ & 0.8681 & & & $\mathrm{~V}$ & 0.4449 & $\mathrm{Ti}$ & 0.5351 & SR & 0.7308 & $\mathrm{CU}$ & 0.6592 & & \\
\hline & $\mathrm{Fe}$ & 0.8623 & & & & & & & ZR & 0.7171 & SN & 0.6449 & & \\
\hline & $\mathrm{Ba}$ & 0.8110 & & & & & & & $\mathrm{ZN}$ & 0.6299 & $\mathrm{ZN}$ & 0.5943 & & \\
\hline & Co & 0.7552 & & & & & & & $\mathrm{CU}$ & 0.6253 & SB & 0.5555 & & \\
\hline & $\mathrm{Zr}$ & 0.5769 & & & & & & & SB & 0.6170 & FE & 0.5360 & & \\
\hline & $\mathrm{Mn}$ & 0.4011 & & & & & & & $\mathrm{CR}$ & 0.6098 & & & & \\
\hline & & & & & & & & & $\mathrm{SN}$ & 0.5321 & & & & \\
\hline & & & & & & & & & $\mathrm{MN}$ & 0.5143 & & & & \\
\hline & & & & & & & & & NI & 0.4412 & & & & \\
\hline & & & & & & & & & BA & 0.4292 & & & & \\
\hline & $\%$ & 44.4 & & 9.9 & & 8.9 & & 7.2 & $\%$ & 56.0 & & 8.1 & & \\
\hline & & Mineral & & Ind.-1+traffic & & Traffic & & Ind.-2 (+fuel oil) & & \multicolumn{5}{|c|}{ Mixed sources (min.+ind.+traffic) } \\
\hline \multirow{12}{*}{$\frac{i}{\sum_{0}^{0}}$} & $\mathrm{BA}$ & 0.9047 & $\mathrm{ZN}$ & 0.9560 & $\mathrm{SN}$ & 0.8554 & TI & 0.7026 & PB & 0.8993 & $\mathrm{BA}$ & 0.9370 & $\mathrm{CR}$ & 0.8495 \\
\hline & SR & 0.7412 & MN & 0.7247 & SB & 0.6483 & V & 0.7022 & NI & 0.8855 & FE & 0.8813 & TI & 0.6006 \\
\hline & FE & 0.7376 & PB & 0.5943 & PB & 0.5976 & NI & 0.5999 & SN & 0.8810 & SR & 0.8801 & & \\
\hline & $\mathrm{ZR}$ & 0.7332 & $\mathrm{CD}$ & 0.5364 & NI & 0.5637 & $\mathrm{CR}$ & 0.4735 & $\mathrm{CD}$ & 0.8671 & ZR & 0.6050 & & \\
\hline & $\mathrm{CU}$ & 0.6131 & $\mathrm{CU}$ & 0.3973 & RB & 0.5057 & & & SB & 0.8523 & MN & 0.5829 & & \\
\hline & SB & 0.5586 & & & $\mathrm{CR}$ & 0.5026 & & & $\mathrm{ZN}$ & 0.8155 & $\mathrm{RB}$ & 0.5494 & & \\
\hline & SE & 0.4646 & & & $\mathrm{CD}$ & 0.4853 & & & $\mathrm{CU}$ & 0.8019 & $\mathrm{CU}$ & 0.4093 & & \\
\hline & & & & & $\mathrm{CU}$ & 0.4640 & & & RB & 0.6670 & $\mathrm{ZN}$ & 0.4007 & & \\
\hline & & & & & & & & & MN & 0.6560 & & & & \\
\hline & & & & & & & & & V & 0.5659 & & & & \\
\hline & & & & & & & & & ZR & 0.5116 & & & & \\
\hline & $\%$ & 39.3 & & 12.6 & & 9.4 & & 5.9 & $\%$ & 59.4 & & 10.7 & & 6.1 \\
\hline
\end{tabular}

\subsection{Size fractionation}

In order to observe patterns of PM size distribution for each metal, finest and coarsest $\left(\mathrm{PM}_{1}\right.$ and $\left.\mathrm{PM}_{10}\right)$ concentrations were compared for each site and campaign (Fig. 7). Metals that are especially concentrated in the $\mathrm{PM}_{1}$ fraction in the $\mathrm{BCN}$ samples $\left(\mathrm{PM}_{1} / \mathrm{PM}_{10}>0.5\right)$ include $\mathrm{V}, \mathrm{Ni}$ and $\mathrm{Cd}$ for both summer and winter (Fig. 7), while As, Se, Y, some $\mathrm{REE}$ and $\mathrm{U}$ were only finer in the winter. In contrast, metals strongly favouring the coarser fraction $\left(\mathrm{PM}_{1} / \mathrm{PM}_{10}<0.1\right)$ in the urban site are mostly crustal elements such as Ti and $\mathrm{Sr}$, $\mathrm{Li}, \mathrm{Ga}$ and some REE (the latter only during the summer). In the case of MSY winter samples showed more metals especially concentrated in the finer fraction, these being $\mathrm{Ni}$, Se, Y, Cd, most REE and U, with coarse metalliferous PM $(<0.1$ ratio) only being observed in the summer campaign, finer metals during this time of the year included $\mathrm{V}, \mathrm{Ni}, \mathrm{Zr}$, $\mathrm{Cd}, \mathrm{Sn}, \mathrm{Hf}, \mathrm{Pb}$ and $\mathrm{Bi}$ (Fig. 7).

Looking at differences between the day/night samples (only for the winter campaign as $12 \mathrm{~h} \mathrm{PM}_{1}$ was not analysed in the summer), in MSY evening samples tended to be smaller in size, with the exception of $\mathrm{Ni}, \mathrm{Cu}$ and $\mathrm{Bi}$. This is especially clear in the case of crustal elements such as $\mathrm{Li}$, $\mathrm{Ti}, \mathrm{Rb}$ and all REE. In the case of BCN while most of metals also followed this pattern, some as $\mathrm{V}, \mathrm{Cr}, \mathrm{Zr}, \mathrm{Sn}, \mathrm{Sb}, \mathrm{Ba}$, and $\mathrm{Pb}$ were preferentially concentrated in the finer fractions in the daytime samples.

\subsection{Metalliferous pollution incidents}

Although trace elemental concentrations are low in mass and therefore are not main components of total PM mass, it is 


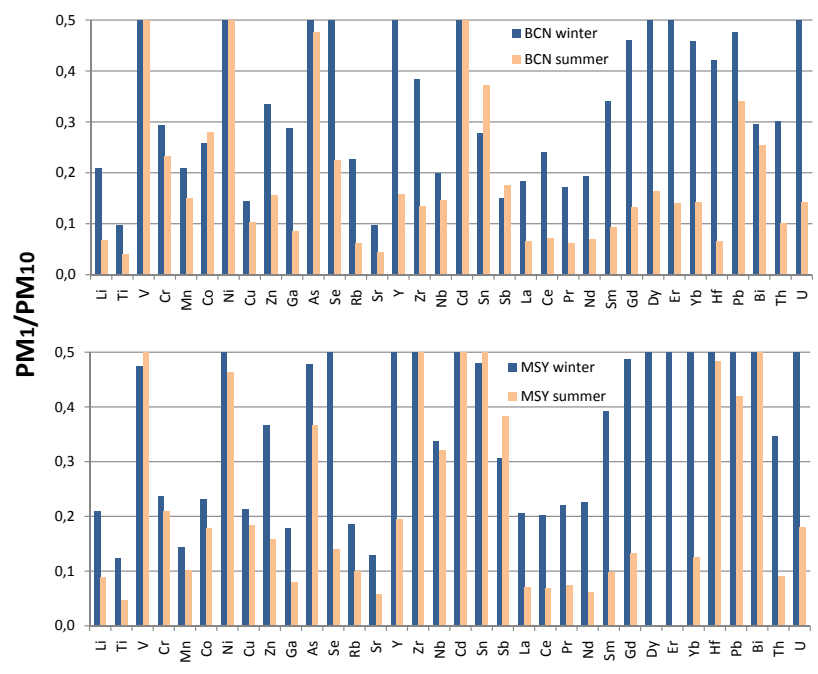

Fig. 7. $\mathrm{PM}_{1} / \mathrm{PM}_{10}$ ratios of average trace metal concentrations measured in $\mathrm{BCN}$ and MSY during the summer and winter campaigns. Metals especially concentrated in the finer fraction in $\mathrm{BCN}$ $\left(\mathrm{PM}_{1} / \mathrm{PM}_{10}>0.5\right)$ include $\mathrm{V}, \mathrm{Ni}$ and $\mathrm{Cd}$ for both summer and winter. In contrast, metals in the coarser fraction $\left(\mathrm{PM}_{1} / \mathrm{PM}_{10}<0.1\right)$ are mostly crustal elements such as $\mathrm{Ti}$ and $\mathrm{Sr}, \mathrm{Li}, \mathrm{Ga}$ and some REE. In MSY winter samples showed more metals in the fine fraction than in summer, with coarse metalliferous $\mathrm{PM}\left(\mathrm{PM}_{1} / \mathrm{PM}_{10}<0.1\right)$ only being observed in the summer campaign.

important to consider that in $\mathrm{BCN}$ highest $\mathrm{PM}_{10}$ concentrations coincided with highest levels of traffic related metals in winter and with crustal components in summer. On the other hand in the rural site of MSY, due to the more mixed atmospheric conditions, highest concentrations of $\mathrm{PM}_{10}$ correlated with highest concentration of coarse anthropogenic metals (V, Ni, Mn, Cu, Sn, Sb) coming from mixed traffic, industrial and fuel oil combustion in winter, whereas in summer, as in the case of $\mathrm{BCN}$, highest values correspond to crustal components.

In addition to this a detailed study of the geochemical database summarised in Tables 2 and 3 reveals periods of time during both campaigns when the average concentrations of specific metals were anomalously high. The more shortlived of these spikes in metal concentrations, lasting less than $36 \mathrm{~h}$ and involving metal pairings such as $\mathrm{V}-\mathrm{Ni}, \mathrm{Mn}-\mathrm{Cu}$, and $\mathrm{Zn}-\mathrm{Pb}$, were most commonly registered during calm winds in $\mathrm{BCN}$, and during the influence of south winds in MSY. Thus they corresponded with stagnating conditions in the city (BCN), and transported plume arrival (MSY). Such events usually occurred at only one or the other of the monitoring sites at a given time, although in the case of $\mathrm{Zn}$ or $\mathrm{Pb}$, transient peaks of these metals during the winter campaign were occasionally registered simultaneously at both $12 \mathrm{~h}$ filters in $\mathrm{BCN}$ and MSY. These transient peaks being so short in time (hours) seem to be related to specific sources, thus V-Ni and $\mathrm{Zn}-\mathrm{Pb}$ are proven tracers of fuel oil combustion and indus- trial emissions respectively (Amato et al., 2011), whereas in the case of $\mathrm{Mn}-\mathrm{Cu}$ this association is not typical of a single source and it is probably more related to mixtures of traffic and industrial emissions. These metal associations are in agreement with the PCA results (Table 4) for the finer PM fractions in both sites and also with the PMF results from studies on previous BCN continuous measurements (Pérez, $2010)$ identifying trace metals in mineral matter $(\mathrm{Li}, \mathrm{Ti}, \mathrm{Rb}$, $\mathrm{Sr}, \mathrm{La}, \mathrm{Ce})$, road traffic $(\mathrm{Cu}, \mathrm{Cr}, \mathrm{Sn}, \mathrm{Sb})$, industrial emissions $(\mathrm{Pb}, \mathrm{Zn}, \mathrm{Cd}, \mathrm{As}, \mathrm{Mn})$ and fuel oil combustion $(\mathrm{V}, \mathrm{Ni})$ factors.

Several of the more extended episodes of high metal concentrations, of at least 2 days duration, happened partly simultaneously in both sites. In this context, during the winter campaign there were three prominent metalliferous pollution episodes all under light, variable winds: (i) 27 February-2 March 2009 (BCN) and 27-28 February 2009 (MSY) with high levels of Sb, Sn, V, Ni and Mn; (ii) 13-17 March 2009 (BCN) and 11-13 March 2009 (MSY) with elevated levels of $\mathrm{Zn}, \mathrm{Se}, \mathrm{Ni}, \mathrm{Sn}, \mathrm{Pb}, \mathrm{Mn}$ (plus $\mathrm{Cr}$ in MSY), and (iii) 23-25 March 2009 (BCN and MSY) with elevated levels of crustal elements. During the summer four main metalliferous episodes were identified: (i) 1-5 July 2009 (BCN and MSY) with $\mathrm{Pb}, \mathrm{Mn}, \mathrm{Cd}, \mathrm{Zn}$, Sn under W-S winds, (ii) V, Ni, Sb, La, Sn, Ti from 14-16 July 2009 (E-SE winds, only recorded in BCN), (iii) Cd, As, V, Ni during 21-23 July 2009 (SW winds only recorded in $\mathrm{BCN}$ ), whereas these same dates MSY showed more clearly the impact of the arrival of air masses from north Africa with high levels of crustal metals; (iv) 26-28 July 2009 with $\mathrm{As}, \mathrm{Sr}, \mathrm{Pb}, \mathrm{Zn}, \mathrm{Cu}(\mathrm{BCN})$ whereas in MSY during 27-29 July 2009 there were higher concentrations of $\mathrm{Ti}$ and $\mathrm{Mn}$, and, to a lesser extent, $\mathrm{Cu}, \mathrm{Sr}, \mathrm{Zr}$, both under predominantly SW winds. In the case of these days-long episodes a mixture of pollutant sources is more probable than in shorter pollution episodes, and thus the elements jointly enhanced during such episodes are linked to traffic $(\mathrm{Sn}, \mathrm{Sb})$, fuel oil combustion $(\mathrm{V}, \mathrm{Ni})$ and metallurgical emissions ( $\mathrm{Zn}, \mathrm{Pb}, \mathrm{Mn}$ ), favouring the idea of mixture of atmospheric pollutants and the difficulty of identifying individual sources as described in source apportionment results (Table 4). Overviewing the database it is clear that most metals showed their highest concentrations jointly with others, producing a "cocktail-effect" polymetallic spike. This was especially the case during the daytime in the summer campaign, whereas during winter these spikes occurred irrespective of the time of day.

Summarising, the geographic setting of BCN and MSY, linked by the same sea-land breeze recirculation system, results in the transport and dispersion of atmospheric pollutants between the two sites (50 km apart). This produces high concentrations of urban pollutants during the day introduced inland by the sea breeze, followed by a reversal of wind direction and a clearing out of pollutants during the night. Among the most obvious tracers for this recirculation system are the metals present in the particulate matter. Highest absolute metal concentrations are shown by $\mathrm{Zn}$ and $\mathrm{Ti}$ at both $\mathrm{BCN}$ 
and MSY, but when compared with Upper Continental Crust the metallic elements $\mathrm{V}, \mathrm{Pb}, \mathrm{Cu}, \mathrm{Zn}, \mathrm{Mn}, \mathrm{Sn}, \mathrm{Bi}, \mathrm{Sb}$ and $\mathrm{Cd}$ are the most atmospherically enriched. The size of these metaliferous particles is variable, with the finest metals at both $\mathrm{BCN}$ and MSY including $\mathrm{V}, \mathrm{Ni}$ and $\mathrm{Cd}$ for both summer and winter, whereas crustal metals ( $\mathrm{Ti}, \mathrm{Sr}, \mathrm{Li}, \mathrm{Rb}$ ) are most abundant in the coarsest inhalable PM size fraction.

In general daytime atmospheric metals are greater in size and more abundant than during night at both sites (although some traffic and industrial-related metals are finer during the day in the case of $\mathrm{BCN}$ ). Hourly data from $\mathrm{BCN}$ show metal concentrations differences during the daytime with traffic related metals (e.g. $\mathrm{Cu}, \mathrm{Sb}, \mathrm{Sn}, \mathrm{Ba}$ ) recording two peaks coinciding with rush hours, whereas industrial and metallurgical metals (e.g. Ni, Mn, Cr) only show an early morning peak produced by contaminated inland valley plumes driven seaward into the city. In MSY, by contrast, most metals show a single concentration peak at midday, heralding the arrival of contaminated urban and industrial air masses from the coast and demonstrating the negative influence of Barcelona on the air quality of surrounding areas.

\section{Discussion and conclusions}

It is clear from our data that the chemical mixture of trace metals breathed at any given place varies enormously. To our knowledge no other study has combined such a wealth of geochemical data to define both short and long-term variations in inhalable metal concentrations within a major city. Previous source apportionment studies applied to the BCN site have identified various sources relevant to metal PM emissions, including vehicle exhaust ( $\mathrm{Sn}$, As and $\mathrm{Cd}$ ), mineral dust ( $\mathrm{Ti}, \mathrm{Sr}, \mathrm{Rb}$ and $\mathrm{Mn})$, road dust ( $\mathrm{Cu}, \mathrm{Sb}, \mathrm{Cr}$ and $\mathrm{Sn}$ ), fuel oil combustion $(\mathrm{V}, \mathrm{Ni})$ and metallurgical industrial processes (Pb, Zn, Sb, Mn, and Cd) (PMF; Amato et al., 2009b; Pey et al., 2009). At the rural site (MSY), fewer specific source factors have been identified due to PM mixing and dilution during wind-blown transport. PCA applied to the hourly concentration data in this study also identified mineral, traffic and industry sources in BCN, whereas in MSY sources were not so clear in the finer PM fraction. As emphasised by one of our referees, the wealth of new chemical information stored in the DAURE database invites future attempts to apply sophisticated source/receptor models which should help us define with more confidence the contributions of different sources to metal levels in the city and surrounding areas.

In the urban environment of Barcelona, as with other cities, build-up of these technogenic pollutants is typically favoured by stagnant atmospheric conditions during winter thermal inversions within a thin, densely polluted mixing layer. Thus we observe during winter in Barcelona the average concentrations of $\mathrm{Pb}, \mathrm{Cu}, \mathrm{Zn}, \mathrm{Mn}, \mathrm{Bi}, \mathrm{Sb}$ and $\mathrm{Cd}$ in $\mathrm{PM}_{10}$ are all $>40 \%$ higher than in summer. In contrast, the remote mountainous site of Montseny shows higher levels of most $\mathrm{PM}_{10}$ inhalable metals in summer. A summer increase in inhalable metal concentrations at MSY was predicted, due to the effect of a thicker tropospheric mixing layer facilitating the intrusion of contaminated urban plumes higher into the mountains. Some of this summer increase at MSY can be attributed to higher levels of crustal particles, this for example producing highest campaign $\mathrm{PM}_{10}$ averages of $\mathrm{Ti}$ and REE.

Another important contribution of this paper is the chemical analysis of different size fractions within the outreaching urban plume at a relatively remote mountainous site (MSY) beyond the city. In this context the interesting observation that the finest $\mathrm{PM}_{1}$ fraction has higher winter concentrations of metals at MSY but not in summer highlights a key difference between the city centre and contaminated hinterland (Fig. 4). At MSY the summer air is more contaminated by the coarser $\mathrm{PM}$ fraction $\left(\mathrm{PM}_{10}\right)$ whereas the winter air has relatively finer $\mathrm{PM}\left(\mathrm{PM}_{1}\right)$. We attribute this seasonal difference to the thicker summer atmospheric mixing layer allowing intrusion of coarser PM higher into the mountains. During the winter, these coarser particles remain trapped at lower altitudes whereas contaminated finer PM are still able to rise high enough to reach the MSY monitoring site. The seasonal variations trends within BCN and MSY must also be understood taking into account the synoptic scenario in the Western Mediterranean Basin. Summer regional episodes when PM is transported from urban/industrial to rural sites by meso-scale circulations has already been described by previous works (e.g. Millán et al., 1997; Rodríguez et al., 2003). During these episodes local wind circulations dominate the atmospheric dynamics in the area, helping the regional accumulation of pollutants and resulting in enhanced aerosol concentrations in MSY due to the scarce renovation of air masses (Rodríguez et al., 2002; Pey et al., 2009). It is also important to consider the effect of local meteorological conditions with a sea breeze regime (developing around 10:00 UTC) strong enough to bring coastal air masses several kilometers inland even in winter. Thus the MSY main wind directions (SE-NW) help channeling the air masses with urban contaminants (for a detailed description of the meteorological overview during the DAURE campign see Jorba et al., 2011).

The summer increases in both $\mathrm{V}$ and $\mathrm{Ni}$ shown by our database stand out as a special case. These high summer levels are presumably also the result of anthropogenic contamination, and the fact that concentrations of both elements at MSY are not negligible suggests a regional-scale influence. Vanadium and $\mathrm{Ni}$ are the most abundant metals present in crude oil, commonly in concentrations that exceed $1000 \mathrm{ppmV}$ and $100 \mathrm{ppmNi}$ (Moreno et al., 2010 and references therein). Oil combustion-related atmospheric emissions of Ni have around doubled and V tripled since the early 1980s, with an estimated 240000 tonnes of V being globally emitted annually by 1995 (Pacyna and Pacyna, 2001). Much 
of this combustion-derived atmospheric $\mathrm{V}$ and $\mathrm{Ni}$ is present in the finest PM size fraction, and is therefore capable of travelling large distances. In our database, $\mathrm{PM}_{1} / \mathrm{PM}_{10}$ values for these two metals are indeed among the highest $(>0.45$ for both sites, Fig. 7) making the combustion of heavy hydrocarbons the primary suspect for $\mathrm{V} / \mathrm{Ni}$ pollution at $\mathrm{BCN}$ and MSY.

Unfortunately, however, distinguishing between the presence of $\mathrm{V}$ and $\mathrm{Ni}$ in crustal versus anthropogenic PM is hampered by the considerable overlap between $\mathrm{V} / \mathrm{Ni}$ values in natural mineral dusts and combustion emissions. The average value for V/Ni in UCC is around 2, with most sedimentary rocks, the finer fractions of soils, and ambient atmospheric PM exhibiting values confined within a range of 1-4 (Rudnick and Gao, 2004; Pey et al., 2009). Similarly, V/Ni values in low-sulphur petcoke and fuel oils typically lie a range of $1-3$, increasing to 4-8 in high sulphur residues such as petcoke and the cheaper bunker oils used as fuel by shipping on the open seas where harbour controls on sulphurous emissions do not apply (Moreno et al., 2010; Pandolfi et al., 2011a). In the case of the MSY and BCN averaged data, all three PM size fractions show a range in V/Ni of 1-3, making unlikely any significant influence from high-sulphur shipping emissions (although individual hourly V/Ni ratios could exceed this value, due to the influence of industrial local emissions or the sporadic arrival of air masses contaminated by the use of less clean oils). In addition, average $\mathrm{La} / \mathrm{Ce}$ values are consistently $<0.55$, ruling out any major contribution from fluid catalytic converter (FCC) oil refineries (Moreno et al., 2008a, b; Sánchez de la Campa et al., 2011). Rather than invoking refinery or open sea shipping emissions, therefore, we suggest instead that the raised levels in atmospheric $\mathrm{V}$ and $\mathrm{Ni}$ at our urban and rural sites as most probably derived from the regional-scale dispersal of low-sulphur fuel oil combustion plumes such as those emanating from industrial smokestacks and shipping emissions close to land where fuel controls apply.

Perhaps the best illustration of the temporal variability of inhalable metal pollutants in and around our cities comes from our data on hourly levels (Fig. 6). At our urban background site within Barcelona locally sourced metalliferous PM concentrations derived from traffic flow exhibit a classic double peak rush-hour pattern. During the mornings the first of these peaks is supplemented by raised levels of metalliferous pollutants which we attribute to industrial sources lying outside the city. This additional influence is characterised by increased levels of specific metals, notably $\mathrm{Cr}$ and Ni (a source shown by PCA in all three PM sizes, Table 4), which suggest a metallurgical source such as stainless steel manufacture. This extra component of air pollution affecting the city results from the distinctive orographic character of Barcelona, lying on the coast adjacent to the CCR (Fig. 1). Thus the city is contaminated by the outpouring of inlandderived industrial pollution on land breezes overnight combined with the containment and blowback of the resulting plumes during wind reversal and the onset of daytime sea breezes. It will presumably be the case that every city will display distinctive microclimatic controls on air movements, superimposing added complexity on the typical double-peak traffic-derived PM concentrations.

Different again from the patterns detected at $\mathrm{BCN}$ is the long afternoon peak exhibited by hourly concentrations of metalliferous PM at MSY, emphasising the severe impact of urban/industrial pollution plumes on outlying, apparently pristine areas. Our hourly data were only obtained during the winter campaign, but, given the $12 \mathrm{~h}$ summer database, it seems likely that the spread of contaminated air into the Montseny hills during summer days is greater still. Once again the coastal location and orography provide a controlling influence, more important than the individual emissions sources (as seen by PCA results), with urban contaminants brought in by sea breezes which maintain higher levels during the whole day until the mountain breeze cleanses the air in the evening (Pérez et al., 2008).

The severity of urban pollution by trace metals, its chemical character, and its outreach to surrounding areas will depend on a complex interplay of factors that include local geomorphology, annual and daily meteorological variations, patterns of road use and specific contributions from industrial hotspots. The detailed chemical database presented in this paper demonstrates in more detail than previous studies the spatial and temporal variability of atmospheric trace metal content that is a likely characteristic of all major cities and their surroundings, and offers insight into the controls on metalliferous particle size segregation and their transportation. The various cocktails of technogenic metalliferous aerosols are typically extremely fine in size and therefore potentially bioavailable, making a good case for basing urban background PM characterisation not only on physical parameters such as mass but also on sample chemistry and with special emphasis on trace metal content.

Acknowledgements. This work was funded by the Spanish Ministry of the Science and Innovation (CGL2007-30502-E/CLI), the Ministry of the Environment and Rural and Marine Affairs (010/PC08/3-04.1), and research projects CARIATI-CGL200806294 and GRACCIE-CSD2007-00067.

Edited by: U. Pöschl

\section{References}

Alastuey, A., Querol, X., Castillo, X., Avila, A., Cuevas, E., Estarellas, C., Torres, C., Exposito, F., García, O., Diaz, J. P., Van Dingenen, R., and Putaud, J. P.: Characterisation of TSP and $\mathrm{PM}_{2.5}$ at Izaña and Sta. Cruz de Tenerife (Canary Islands, Spain) During a Saharan Dust Episode (July 2002), Atmos. Environ. 39, 4715-4728, 2005.

Amato, F., Pandolfi, M., Viana, M., Querol, X., Alastuey, A., and Moreno, T.: Spatial and chemical patterns of $\mathrm{PM}_{10}$ in road 
dust deposited in urban environment, Atmos. Environ. 43, 16501659, 2009a.

Amato, F., Pandolfi, M., Escrig, A., Querol, X., Alastuey, A., Pey, J., Perez, N., and Hopke, P. K.: Quantifying road dust resuspension in urban environment by Multilinear Engine: a comparison with PMF2, Atmos. Environ. 43, 2770-2780, 2009 b.

Amato, F., Viana, M., Richard, A., Furger, M., Prévôt, A. S. H., Nava, S., Lucarelli, F., Bukowiecki, N., Alastuey, A., Reche, C., Moreno, T., Pandolfi, M., Pey, J., and Querol, X.: Size and timeresolved roadside enrichment of atmospheric particulate pollutants, Atmos. Chem. Phys., 11, 2917-2931, doi:10.5194/acp-112917-2011, 2011.

Azimi, S., Ludwig, A., Thévenot, D., and Colin, J. L.: Trace metal determination in total atmospheric deposition in rural and urban areas, Sci. Tot. Environ., 308, 247-256, 2003.

Birmili, W., Allen, A., Bary, F., and Harrison, R.: Trace Metal Concentrations and Water Solubility in Size-Fractionated Atmospheric Particles and Influence of Road Traffic, Environ. Sci. Technol., 14, 1144-1153, 2006.

Bukowiecki, N., Lienemann, P., Hill, M., Figi, R., Richard, A., Furger, M., Rickers, K., Falkenberg, G., Zhao, Y., Cliff, S. S., Prevot, A. S. H., Baltensperger, U., Buchmann, B., and Gehrig, R.: Real-world emission factors for antimony and other brake wear related trace elements: Size-segregated values for light and heavy duty vehicles, Environ. Sci. Technol., 43, 8072-8078, 2009.

Bukowiecki, N., Lienemann, P., Hill, M., Furger, M., Richard, A., Amato, F., Prevot, A., Baltensperger, U., Buchmann, B., and Gehrig, R.: PM 10 emission factors for non-exhaust particles generated by road traffic in an urban street canyon and along a freeway in Switzerland, Atmos. Environ., 44, 2330-2340, 2010.

Council Directive 1999/30/EC; Council Directive 1999/30/EC of 22 April 1999 relating to limit values for sulphur dioxide, nitrogen dioxide and oxides of nitrogen, particulate matter and lead in ambient air. Official Journal of the European Communities L163, 41-60, 1999.

Escudero, M., Querol X., Ávila, A., and Cuevas, E.: Origin of the exceedances of the European daily PM limit value in regional background areas of Spain, Atmos. Environ., 41, 730-744, 2007.

Gavett, S. H., Haykal-Coates, N., Copeland, L. B., Heinrich, J., and Gilmour, M. I.: Metal Composition of Ambient $\mathrm{PM}_{2.5}$ Influences Severity of Allergic Airways Disease in Mice, Environ. Health Perspect., 111, 1471-1477, doi:10.1289/ehp.6300, 2003.

Guastadisegni, C., Kelly, F. J., Cassee, F. R., Gerlofs-Nijland, M. E., Janssen, N. A., Pozzi, R., Brunekreef, B., Sandstrom, T., and Mudway, I. S.: Determinants of the Proinflammatory Action of Ambient Particulate Matter in Immortalized Murine Macrophages, Environ. Health Perspect., 118, 17281734, doi:10.1289/ehp.1002105, 2010.

Harrison, R. M. and Williams, C.: Airborne cadmium, lead and zinc at rural and urban sites in north-west England, Atmos. Environ., 16, 2669-2651, 1982.

Jorba, O., Pandolfi, M., Spada, M., Baldasano, J. M., Pey, J., Alastuey, A., Arnold, D., Sicard, M., Artiñano, B., Revuelta, M. A., and Querol, X.: The DAURE field campaign: meteorological overview, Atmos. Chem. Phys. Discuss., 11, 4953-5001, doi:10.5194/acpd-11-4953-2011, 2011.

Ledoux, F., Laversin, H., Courcot, D., Courcot, L., Zhilinskaya, L., Puskaric, E., and Aboukaïs, A.: Characterization of iron and manganese species in atmospheric aerosols from anthropogenic sources, Atmos. Res., 82, 633-642, 2006.

Lin, C., Chen, S. and Huang, K.: Characteristics of metals in nano/ultrafine/fine/coarse particles collected beside a heavily trafficked road, Environ. Sci. Technol., 39, 8113-8122, 2005.

Milford, J. and Davidson, C.: The sizes of particulate trace elements in the atmosphere, J. Air Pollut. Control Assoc., 35, 1249-1260, 1985.

Millán, M., Salvador, R., Mantilla, E., and Kallos, G.: Photooxidant dynamics in the Mediterranean basin in summer: results from European research projects, J. Geophys. Res., 102, 88118823, 1997.

Moreno, T., Querol, X., Alastuey, A., Viana, M., Salvador, P., Sánchez-Campa, A., Artiñano, B., Rosa, J., and Gibbons, W.: Variations in atmospheric PM trace metal content in Spanish towns: Illustrating the chemical complexity of the inorganic urban aerosol cocktail, Atmos. Environ., 40, 6791-6803, 2006.

Moreno, T., Querol, X., Alastuey, A., Ballester, F., and Gibbons, W.: Airborne particulate matter and premature deaths in urban Europe: the new WHO guidelines and the challenge ahead as illustrated by Spain, Europ. J. Epidemiol., 22, 1-5, 2007.

Moreno, T., Querol, X., Alastuey, A., Pey, J., Minguillón, M. C., Pérez, N., Bernabé, R. M., Blanco, S., Cárdenas, B., and Gibbons, W.: Lanthanoid geochemistry of urban atmospheric particulate matter, Environ. Sci. Technol., 42, 6502-6507, 2008a.

Moreno, T., Querol, X., Alastuey, A., and Gibbons, W.: Identification of FCC refinery atmospheric pollution events using lanthanoid- and vanadium-bearing aerosols, Atmos. Environ., 42, 7851-7861, 2008b.

Moreno, T., Querol, X., Alastuey, A., de la Rosa, J., SanchezCampa, A., Minguillon, Mc., Pandolfi, M., Gonzalez-Castanedo, Y., Monfort, E., and Gibbons, W.: Variations in vanadium, nickel and lanthanoid element concentrations in urban air, Sci. Total Environ., 408, 4569-4579, 2010.

Pacyna, J. M.: Source-receptor relationships for trace elements in Northern Europe, Water Air Soil Pollut., 30, 825-835, 1986.

Pacyna, J. M. and Pacyna, E. G.: An assessment of global and regional emissions of trace metals to the atmosphere from anthropogenic sources worldwide, Environ. Rev., 9, 269-298, 2001.

Pakkanen, T., Loukkola, K., Korhonen, C., Aurela, M., Mäkelä, T., Hillamo, R., Aarnio, P., Koskentalo, T., Kousa, A., and Maenhaut, W.: Sources and chemical composition of atmospheric fine and coarse particles in the Helsinki area, Atmos. Environ., 35, 4593-4607, 2001.

Pandolfi, M., Gonzalez-Castanedo, Y., Alastuey, A., de la Rosa, J., Mantilla, E., Sanchez de la Campa, A., Querol, X., Pey, J., Amato, F., and Moreno, T.: Source apportionment of $\mathrm{PM}_{10}$ and $\mathrm{PM}_{2.5}$ at multiple sites in the strait of Gibraltar by PMF: impact of shipping emissions, Environ. Sci. Pollut. Res., 18, 260-269, 2011a.

Pandolfi, M., Querol, X., Alastuey, A., Jimenez, J., Jorba, O., Stohl, A., Comerón, A., Sicard, M., Pey, J., vanDrooge, B. and DAURE team: Source and origin of PM in the Western Mediterranean Basin: An Overview of the DAURE campaign, Atmos. Chem. Phys. Discuss., submitted, 2011b.

Pérez, N.: Variablity of atmospheric aerosols at urban, regional and continental backgrounds in the Western Mediterranean basin, PhD Thesis, Universitat Autonoma de Barcelona, 392 pp., 2010

Pérez, N., Pey, J., Castillo, S., Alastuey, A., Querol, X., and 
Viana, M.: Interpretation of the variability of regional background aerosols in the Western Mediterranean, Sci. Total Environ., 407, 527-540, 2008.

Pey, J., Pérez, N., Castillo, S., Viana, M., Moreno, T., Pandolfi, M., López-Sebastián, J. M., Alastuey, A., and Querol, X.: Geochemistry of regional background aerosols in the Western Mediterranean, Atmos. Res., 94, 422-435, 2009.

Pey, J., Pérez, N., Querol, X., Alastuey, A., Cusack, M., and Reche, C.: Intense winter atmospheric pollution episodes affecting the Western Mediterranean, Sci. Total Environ., 408, 1951-1959, 2010a.

Pey, J., Querol, X., and Alastuey, A.: Discriminating the regional and urban contributions in the North-Western Mediterranean: PM levels and composition, Atmos. Environ., 44, 1587-1596, 2010b.

Querol, X., Alastuey, A., De La Rosa, J., Sanchez, A., Plana, F., and Ruiz, C. R.: Source apportionment analysis of atmospheric particulates in an industrialised urban site in south-western Spain, Atmos. Environ., 36, 3113-3125, 2002.

Querol, X., Pey, J., Minguillón, M. C., Pérez, N., Alastuey, A., Viana, M., Moreno, T., Bernabé, R. M., Blanco, S., Cárdenas, B., Vega, E., Sosa, G., Escalona, S., Ruiz, H., and Artíñano, B.: PM speciation and sources in Mexico during the MILAGRO-2006 Campaign, Atmos. Chem. Phys., 8, 111-128, doi:10.5194/acp8-111-2008, 2008.

Querol, X., Pey, J., Pandolfi, M., Alastuey, A., Cusack, M., Pérez, N., Moreno, T., Viana, M., Mihalopoulos, N., Kallos, G., and Kleanthous, S.: African dust contributions to mean ambient $\mathrm{PM}_{10}$ mass-levels across the Mediterranean Basin, Atmos. Environ., 43, 4266-4277, 2009.

Reche, C., Viana, M., Moreno, T., Querol, X., Alastuey, A., Pey, J., Pandolfi, M., Prevot, A., Mohr, C., Richard, A., Artíñano, B., Gomez-Moreno, F., and Cots, N.: Peculiarities in atmospheric particle number and size-resolved speciation in an urban area in the western Mediterranean: results from the DAURE campaign, Atmos. Environ, 45, 5282-5293, 2011.

Richard, A., Bukowiecki, N., Lienemann, P., Furger, M., Fierz, M., Minguillón, M. C., Weideli, B., Figi, R., Flechsig, U., Appel, K., Prévôt, A. S. H., and Baltensperger, U.: Quantitative sampling and analysis of trace elements in atmospheric aerosols: impactor characterization and Synchrotron-XRF mass calibration, Atmos. Meas. Tech., 3, 1473-1485, doi:10.5194/amt-3-14732010, 2010.
Rodríguez, S., Querol, X., Alastuey, A., Kallos, G., and Kakaliagou, O.: Saharan dust contributions to $\mathrm{PM}_{10}$ and TSP levels in Southern and Eastern Spain, Atmos. Environ., 35, 2433-2447, 2001.

Rodríguez, S., Querol, X., Alastuey, A., and Plana, F.: Sources and processes affecting levels and composition of atmospheric aerosol in the western Mediterranean, J. Geophy. Res., 107(D24), 4777, doi:10.1029/2001JD001488, 2002.

Rodríguez, S., Querol, X., Alastuey, A., Viana, M., and Mantilla, E.: Events Affecting Levels and Seasonal Evolution of Airborne Particulate Matter Concentrations in the Western Mediterranean, Environ. Sci. Technol., 37, 216-222, 2003.

Rudnick, R. L. and Gao, S.: Composition of the continental crust. In: Holland HD, Turekian KK,editors. Treatise on Geochemistry, 3. Amsterdam: Elsevier, 1-64, 2004.

Sanchez de la Campa, A., Moreno, T., De La Rosa, J., Alastuey, A., and Querol, X.: Size distribution and chemical composition of metalliferous stack emission particles in the San Roque petroleum refinery complex, southern Spain, J. Hazardous Mat, 190, 713-722, 2011.

Schaumann, F., Born, P., Herbrich, A., Knoch, J., and Pitz, M.: Metal-rich ambient particles $\left(\mathrm{PM}_{2.5}\right)$ cause airway inflammation in healthy subjects, Am. J. Respir. Crit. Care Med., 170, 898903, 2004.

Shah, M. H., Shaheen, N., Jaffar, M., Khalique, A., Tariq, S. R., and Manzoor, S.: Spatial variations in selected metal contents and particle size distribution in an urban and rural atmosphere of Islamabad, Pakistan, J. Environ. Manag., 78, 128-137, 2006.

US EPA: Air quality criteria for particulate matter, US Environmental Protection Agency, Research Triangle Park, NC, EPA/600/P99/002aF-bF, 2004.

US EPA: Integrated Science Assessment for Particulate Matter, December 2009, EPA/600/R-08/139F, 2228 pp., 2009.

Utsunomiya, K., Keeler, J., and Ewing, R.: Direct identification of trace metals in fine and ultrafine particles in the Detroit urban atmosphere, Environ. Sci. Technol., 38, 2289-2297, 2004.

Valko, M., Morris, H., and Cronin, M. T.: Metals, toxicity and oxidative stress, Curr. Med. Chem. 12(10), 1161-1208, 2005.

Wedepohl, K. H.: The composition of the continental crust, Geochem. Cosmochim. Acta, 59, 217-239, 1995.

WHO: Air Quality Guidelines for Europe, 2nd Edition, WHO Regional Office for Europe, Copenhagen, 2000. 